University of Nebraska - Lincoln

DigitalCommons@University of Nebraska - Lincoln

Zea E-Books

Zea E-Books

4-13-2021

Wimmin in the Mass Media

Terry Nygren

Mary Jo Deegan

Follow this and additional works at: https://digitalcommons.unl.edu/zeabook

Part of the Curriculum and Social Inquiry Commons, Educational Methods Commons, Higher Education Commons, Liberal Studies Commons, and the Other Education Commons

This Book is brought to you for free and open access by the Zea E-Books at DigitalCommons@University of Nebraska - Lincoln. It has been accepted for inclusion in Zea E-Books by an authorized administrator of DigitalCommons@University of Nebraska - Lincoln. 


\section{ARTICLES COLLECTED AT \\ THE CENTENNIAL EDUCATION \\ PROGRAM}

FALL, 1980

\section{0th Anniversary Edition}

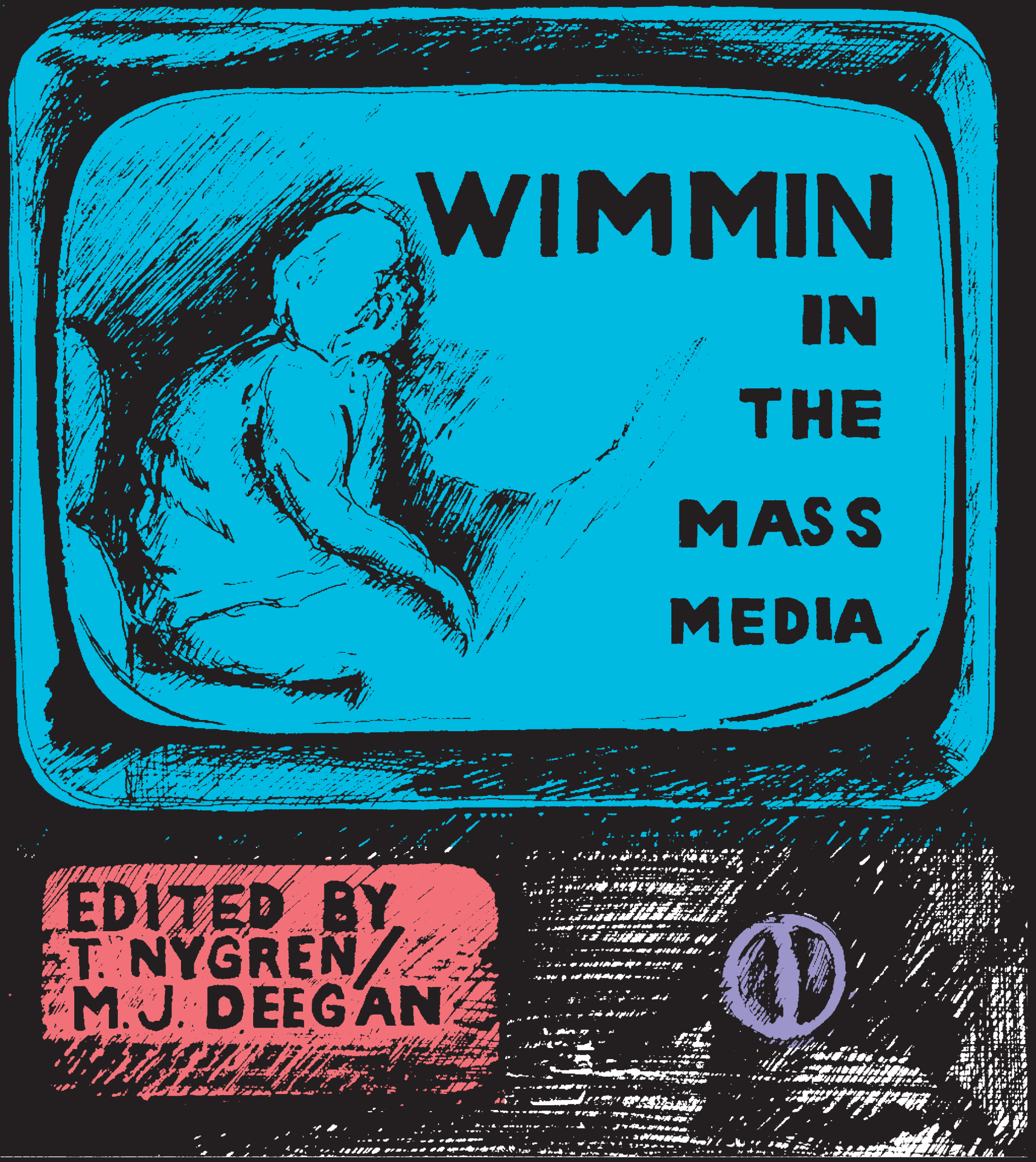




\section{Contents}

Introduction to the 40th Anniversary Edition: Wimmin in the Mass Media and Centennial College, Looking Backwards

Mary Jo Deegan

\section{WIMMIN IN THE MASS MEDIA}

\section{Articles Collected at the Centennial Education Program, Fall 1980}

Introduction: Wimmin and the Mass Media - Construction of the Self Mary Jo Deegan and Terry Nygren

Examining the Top Ten, or Why Those Songs Make the Charts Jane Pemberton

Images of Women in Rock Music: Analysis of B-52's and Black Rose Sheila M. Krueger

Women in Sitcoms: "I Love Lucy"

Nancy Grant-Colson

Horatio Alger is Alive and Well and Masquerading as a Feminist, or Where Are the Magazines for the Real Working Women?

Teresa Holder

Freudian Tradition Versus Feminism in Science Fiction

Karen Keller

Cover based on original design by Becky Ross.

Zea Books

Lincoln, Nebraska

ISBN 978-1-60962-200-8 ebook

doi: $10.32873 /$ unl.dc.zea.1300

Nebrastka 


\title{
WIMMIN IN THE MASS MEDIA
}

Student Articles Written \& Collected at the Centennial Education Program University of Nebraska-Lincoln Fall, 1980

\author{
Edited with an Introduction by \\ TERRY NYGREN and MARY Jo DEEGAN
}

40th Anniversary Edition Edited with a New Introduction by MARY JO DEEGAN

Professor Emerita Department of Sociology University of Nebraska-Lincoln 
Copyright (C) by Mary Jo Deegan 2021

New material in this edition set in Franklin Gothic Book

Pagination of new material appears in square brackets: [ ]

Book design: Michael R. Hill

Jane Addams Research Center Publication Series, No. 1.

This edition produced in association with the

Jane Addams Research Center

Mary Jo Deegan, Executive Director

904 Main Street

St. Joseph, Michigan 49085

\author{
ISBN 978-1-60962-199-5 paperback \\ ISBN 978-1-60962-200-8 ebook \\ doi: $10.32873 /$ unl.dc.zea.1300
}

Zea Books are published by the University of Nebraska-Lincoln Libraries.

Electronic (pdf) edition available online at

https://digitalcommons.unl.edu/cgi/cview.cgi/zeabook

Print edition available from Lulu.com at

https://www.lulu.com/spotlight/unllib

UNL does not discriminate based upon any protected status. Please go to https://www.unl.edu/equity/notice-nondiscrimination

[ii]

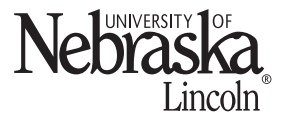


This edition

in memoriam

Terry Rae Nygren

1946 - 2011

and

Robert G. Fuller

1935 - 2012 


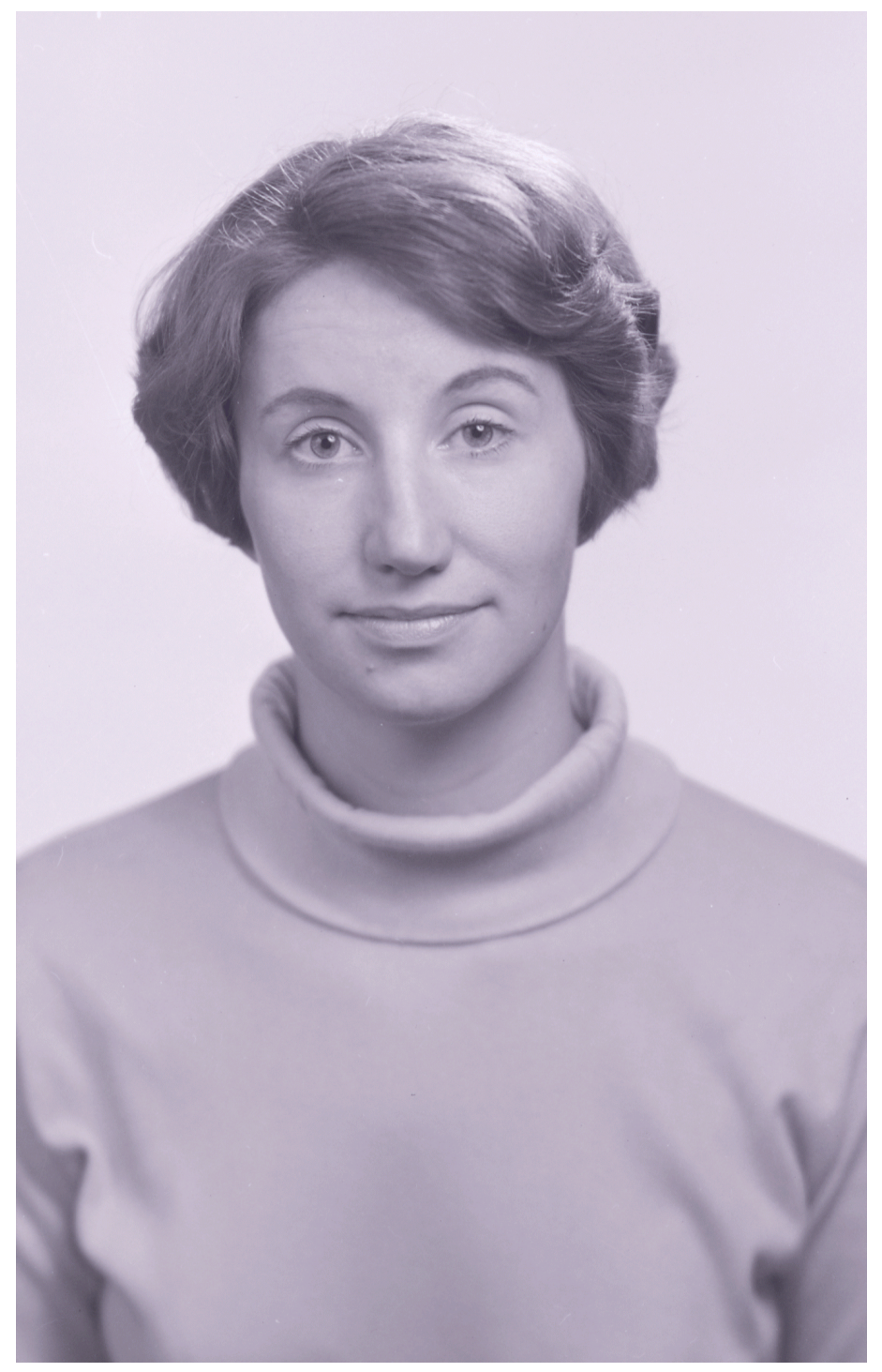

Terry Rae Nygren

Photo courtesy of Archives and Special Collections, University of Nebraska-Lincoln 


\section{Contents}

Introduction to the $40^{\text {th }}$ Anniversary Edition: Wimmin in the Mass Media and

Centennial College, Looking Backwards .............. [vii] Mary Jo Deegan

\section{WIMMIN IN THE MASS MEDIA}

Introduction: Wimmin and the Mass Media - Construction of the Self ...... i Mary Jo Deegan and Terry Nygren

Examining the Top Ten, or Why Those Songs Make the Charts .......... 1 Jane Pemberton

Images of Women in Rock Music: Analysis of B-52's and Black Rose..... 11 Sheila M. Krueger

Women in Sitcoms: "I Love Lucy" ....................... 21

Nancy Grant-Colson

Horatio Alger is Alive and Well and Masquerading as a Feminist, or Where Are the Magazines for the Real Working Women? .......................... 31 Teresa Holder

Freudian Tradition Versus Feminism in Science Fiction ............ 41 Karen Keller

About the Editor and Author of the New Introduction $\ldots \ldots \ldots \ldots \ldots . . . \ldots 33$ 


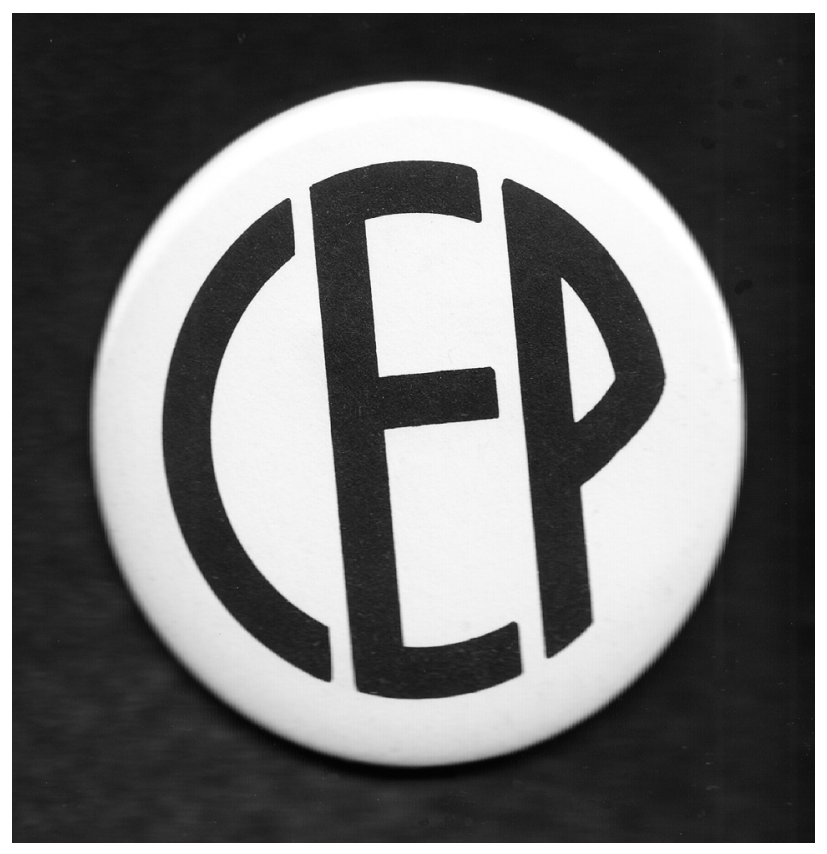

Centennial Education Program

Pin-Back Logo Badge

(diameter $2 \frac{1}{2} 2$ inches)

Personal collection of Mary Jo Deegan 


\title{
Introduction to the $40^{\text {th }}$ Anniversary Edition: Wimmin in the Mass Media and Centennial College, Looking Backwards
}

\author{
Mary Jo Deegan
}

Centennial College was an experimental educational unit (started in 1969) at the University of Nebraska-Lincoln as part of the school's centennial celebration. By 1980 Robert ("Bob") Fuller (a physics professor who was on the cutting-edge of innovative ways to teach the hard sciences), was the director of Centennial College and had written successful grants to fund it ("Robert G. Fuller, Curriculum Vitae", 2007). Centennial College was a new venture for both faculty and students, a way to explore new courses, classroom formats, colleagues, and student networks. The faculty was a mixture of full-time faculty working in traditional programs and ad hoc faculty more loosely tied to the University. In 1980-1981 I was a "fellow" in the program with half of my teaching load in the fall semester of 1980 in the College and an untenured assistant professor in the sociology department. I was recruited into

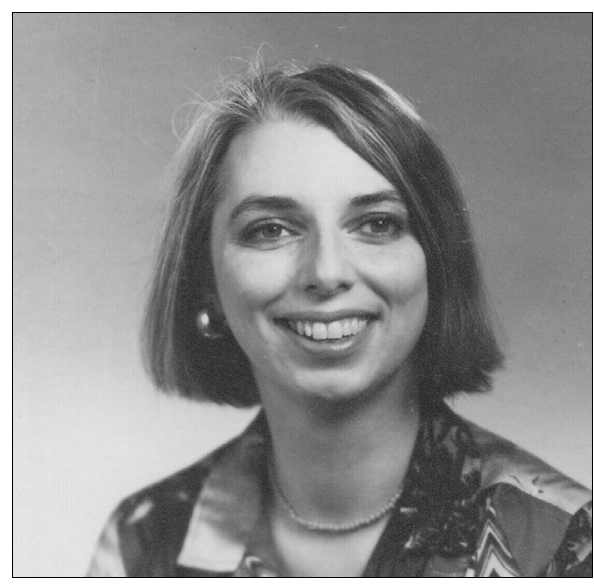

Mary Jo Deegan, circa 1980 the College by Terry Nygren who was an allbut-dissertation graduate student in the English department and the film studies program as well as a member of the ad hoc faculty in the College. Terry and I were feminists and were both interested in the mass media from the standpoint of different disciplines.

In this new introduction to our booklet, Wimmin in the Mass Media, edited by Terry Nygren and myself and sponsored by the Centennial Education Program, I look back on our efforts after teaching for forty years at the University and retiring from it in 2015. This introduction emerges from my perspective as a former fellow in an unusual educational program that ended in 1980 when the 
faculty disbanded and the physical site for the College was vacated and returned to more traditional campus programs. Unfortunately, Terry and Bob, who were much more knowledgeable than I am concerning the origin, life, death of the Centennial organization, have passed: Terry died in 2011 and Bob followed in 2012.

Our booklet was distributed for free primarily to the faculty and students in Centennial College, and, secondarily, to anyone else who was interested. We held panels discussing our work both to the former classmates and for the College and general public. Our audiences for the panels were animated and had passionate opinions on each paper. We sent copies of the booklet to a few libraries ${ }^{1}$ and soon thereafter the College closed its doors.

Our course, "Wimmin in the Mass Media," was offered only once and would be long forgotten if not for this booklet. Because this was an exciting, very short experiment in education, it is worth recalling now, some four decades later. As I am the only surviving instructor who was in close contact with this course, I venture to look backward from 2020 to 1980 . I do this by describing how the course was initiated and functioned, followed by a brief biography of Terry Nygren, my perspective on Centennial, a summary of the classroom experience, our production of the booklet, and the response to it.

ORIGINS OF THE CENTENNIAL EDUCATION PROGRAM, 1969-1971

In 1969 Robert E. Knoll, professor of English, and Robert D. Brown, professor of educational psychology, were part of a committee that reviewed the first hundred years of education at the University of Nebraska. They and other members of the committee decided to look to the future by trying an experiment with an innovative residential "cluster college" which created a small community of faculty and students within the larger university environment. A group of about 150 students out of almost 20,000 made it a very small percentage of the total group. Knoll and Brown (1972) summarized the experiment for the first two years, 1969-1971. Their analysis of student and faculty views was comprehensive, but cracks in the process were clearly part of this foundation.

Knoll and Brown (1972: 59) noted but tried to minimize the perception of the program as "more free-wheeling, leftish, even hippie, than other student groups." They thought this was a temporary perception that would disappear over time as the program was routinized. The Centennial core course had an optional

[viii] 
grade or pass/fail evaluation that the student could select. Few students with grades earned less than an A (Knoll and Brown, 1972: 61-62), and many students thought they could have worked harder. Centennial students especially valued their interactions with other students, even more highly than studentfaculty interactions per se.

This background was unknown to me when I joined Centennial in the fall of 1980. Although I was by then a seasoned assistant professor on the Lincoln campus, I had never actually heard it called Centennial Education Program, but always referred to simply as "Centennial." I and many newer faculty members were unaware of the program's origins, its core curriculum, residential status, or stated mission. In essence, I and many others thought it was an elite, politically active, left-leaning group, with lots of vitality. This perception of the college was one that Knoll and Brown thought was a temporary misunderstanding of the Centennial Education Program in 1972, but this image had grown into a solid campus identity by 1980 .

\section{THE COURSE: “WIMMIN IN THE MASS MEDIA”}

Terry and I met at a feminist conference in the late 1970s. We soon became friends and shared our common interest in the mass media. We talked about co-teaching a course on women and the mass media from our different perspectives and training. I had had several courses at the graduate level at the University of Chicago that used this format and they were the best courses I had taken there. Team teachers could raise interesting questions that students could not articulate, although students often had the same problems accepting or understanding what a lecturer was presenting.

Terry was already on the faculty of Centennial College and they had a program for team teaching for which a faculty member at UNL could apply. I submitted an application and was accepted as a temporary "fellow" of Centennial who was paid to team teach one course, and I was thus excused from teaching one of my courses in the department of sociology. In the fall of 1980 Terry and I offered the course "Wimmin in the Mass Media" adopting the feminist spelling of "Women." This word "wimmin" reflected a popular linguistic movement to define women without using a word that defined them as a 
"subset" of "men." The root of the word was mired in history that literally defined women as dependent upon men.

We distributed a campus flyer describing the course that explained it would be offered only once and would be taught from a feminist perspective. A politically right physics professor (one of Fuller's colleagues) was outraged by this "propaganda" to poison students' minds. He tried to get the course stopped by going to university administrators and by organizing a petition against it. He was unsuccessful in his attempt to censor us and limit our freedom of speech, but he created some on-campus interest in the course. Today such right-wing campus opposition is much more organized and technologically sophisticated (Goodwin and Moynihan, 2011).

The course format and goals were examined in the original introduction to the course that is included here. I can add that the class was lively, and we engaged in a lot of discussions, disagreements, and critique. After each student presented an in-class final paper we were proud of our work and wanted to share it with others in the class. We still wanted to discuss and share our findings more widely. Thus we decided to produce this booklet. It was a voluntary project that was done after the course had ended and grades assigned. We were pleased with the leaflet and the students presented their work to a general campus audience in a panel held within Centennial's classrooms.

Terry and I introduced the course goals and each presenter. We took a little over an hour to do this and then opened for audience comments. There were many. The entire event prompted many questions for Terry and me - were we too hard on the students? Were we innovative or too traditional? Could you teach this course without being feminists? The students were also quizzed, but the audience praised their work first, and the questions were often probing but within a supportive context. Centennial sponsored a brief reception and we were again pleased with our hard work. ${ }^{2}$

I can briefly fill-in some more background to the course.

TERRY NYGREN (1946-2011)

Terry Nygren was born in South Bend, Nebraska, on 30 August 1946. She was the daughter of Earnest and Zine (Laird) Foudray. Terry graduated from Lincoln High School and earned bachelor's and master's degrees from UNL. She studied at the University of Paris for a year and drew on this training for her 
master's thesis. Her obituary stressed her various positions at the Sheldon Museum of Art and with the Mary Riepma Ross Media Arts Center at the university (“Nygren, Terry Rae," 2011; “Terry Rae Nygren,” 2011).

Terry was struggling to complete her doctorate in 1980 and was alienated from traditional classrooms and politics. She experienced a writing block that she never conquered. I mention this fact because it inspired her teaching and intense relationship to education during our course. I too had confronted a writing block and anger with the university establishment (Deegan and Hill 1991) that emerged at least partially from our analysis of the patriarchal culture of academia.

Terry and I worked well together and fully shared our teaching responsibilities. We learned from each other and the students. Our classroom was animated. We would start talking/lecturing and the students jumped into these discussions during each class. We did not have to call on reluctant students to participate.

\section{THE CLOSURE OF CENTENNIAL}

The university was cutting the funding for the Centennial Education Program so a new sponsor was needed. Everyone hoped that new funding was imminent because of a pending grant proposal for "Citizen Advocacy Research Education (CARE) submitted to the Comprehensive Program Fund for the Improvement of Postsecondary Education. Bob Fuller was to be the project director and he asked for $\$ 103,200$. UNL would contribute $\$ 240,000$. Thirty students would be admitted to the program each year. The first year, fall, 1980 (later revised to Fall, 1981), would include faculty consultants who would identify issues and prepare curriculum. I was one of the thirteen slated consultants and attended two meetings on improving the proposal. In the spring, advertisements for the program and applications would be accepted. Students would enroll for 3-6 hours in the fall, 1981 (revised to Fall, 1982). The program would continue for five years. Team projects with reading, application, and research schedules would be developed. Everyone would participate in a seminar. Evaluation of the first year would combine with an emphasis on accomplishing advocacy activities.

This proposal was on the short list for funding in the spring of 1979 and again in 1981. At the latter date, a few meetings were held for faculty input and suggestions. The revised proposal was again not funded and Bob heard the bad 
news in the late spring. The funding agency encouraged re-submission with some minor changes and liked the project. Bob was optimistic about its future funding. He planned to solicit different, smaller funds for a less ambitious program for 1981-1982. He thought the Centennial program could be continued and the CARE program would be a subgroup within Centennial.

Terry telephoned me in the spring, 1981, however, and told me that the faculty of Centennial had to vacate the premises immediately. Although the college had "bought" their equipment from the university and Bob was in the process of searching for new funding, the university would not store the materials associated with the college. The program was closed and anything remaining would be confiscated or appropriated for other campus uses. This epitomized the general campus hostility to the program.

Although everyone knew that the funding from the university had ended, the faculty assumed they had the summer to move from their offices and that perhaps new money would keep the program going. They were shocked by the demand to immediately vacate the premises. The ad hoc faculty, moreover, lost more than their jobs at Centennial, they also lost their homes on campus and their place at the university. This was, of course, difficult for them to assimilate quickly.

I retrieved my few belongings from our office that evening and the classrooms and hallway were empty. Centennial was over. I had just undergone a tenure vote, which I successfully survived. My service at Centennial was not rated positively during this process, however. I was seen as "not pulling my weight" in sociology while having "fun" at Centennial. Our booklet and teaching were defined as "unprofessional." I note this response because it indicates the systematic problems that faced this experiment in teaching by 1980 .

Terry left the university for many years during the 1980s and 1990s and we lost touch with each other. When we occasionally "ran into" each other we remained friends and "caught up" with each other. Centennial college was part of our shared past.

\section{CONCLUSION}

I hope that reprinting this booklet will serve as a small material document of the educational community many of us enjoyed with this program. It is also a reminder of an era and political attempt to broaden the scope of traditional 
formats at the University of Nebraska-Lincoln. Centennial created a short, viable community that is remembered here. In recent years, graduates and participants have gathered to celebrate their Centennial experiences and these events are now documented online via YouTube: 2012, Centennial College Reunion, https://www.youtube.com/watch?v=oSzwlfUr8kY ; Centennial Education Program UNL 2014 Reunion, https://www.youtube.com/watch?v=X82QQT4EKrU; and 2019, Nebraska Lecture with Centennial College Panelists, https://www.youtube.com/watch?v=ExWoT70Vkd0 .

A small collection of related materials is now available in the Archives and Special Collections of the University of Nebraska-Lincoln, "Centennial Education Program (CentEP), Interdisciplinary and Special Programs Records," https://archives.nebraska.edu/repositories/8/resources/3224.

\section{END NOTES}

1. Whereas a recent search via WorldCat (https://www.worldcat.org/) provided a descriptive entry for our booklet, it also noted that no extant copies were available. Thus, the present republication provides general and widespread access to our early, collaborative effort regarding wimmin in the mass media. The essentially facsimile version reproduced below contains only a very few corrections of obvious typographical errors.

2. This format fits the pattern of American rituals, exhibiting a period betwixt and between everyday statuses that has a fixed end and reincorporation with everyday life (Deegan 1989; 1998). 


\section{REFERENCES}

Deegan, Mary Jo. 1989. American Ritual Dramas: Social Rules and Cultural Meanings. Westport, CT: Greenwood Press. .1998. The American Ritual Tapestry: Social Rules and Cultural Meanings. Greenwich, CT: Greenwood Press.

Deegan, Mary Jo, and Michael R. Hill. 1991. "Doctoral Dissertations as Liminal Journeys of the Self: Betwixt and Between in Graduate Sociology Programs." Teaching Sociology 19 (July): 322-332. https://digitalcommons.unl.edu/sociologyfacpub/459/

Goodwin, Amy and Enis Moynihan. 2011. "Andrew Breitbart's ‘Electronic Brownshirts'” Pp. 18890 in The Silenced Majority, edited by Amy Goodwin and Denis Moynihan; foreword by Michael Moore. Chicago: Haymarket Books, 2012.

Knoll, Robert E. and Robert D. Brown. 1972. Experiment at Nebraska: The First Two Years of a Cluster College. Lincoln: University of Nebraska Studies, New Series, No. 44. June. https://digitalcommons.unl.edu/univstudiespapers/57/

“Nygren, Terry Rae." 2011. Lincoln Journal Star (7 September). https://journalstar.com/lifestyles/announcements/obituaries/nygrenterry-rae/article aac47409-39f5-5ab1-87a6-0c445eee4d37.html

Nygren, Terry and Mary Jo Deegan, eds. 1980. Wimmin in the Mass Media. Lincoln: Centennial Education Program, University of Nebraska-Lincoln.

"Robert G. Fuller, Curriculum Vitae". 2007. Robert G. Fuller Publications and Presentations. Paper 4. University of Nebraska-Lincoln, Digital Commons. http://digitalcommons.unl.edu/physicsfuller/4

"Robert Fuller (obituary)". 2012. Robert G. Fuller Publications and Presentations. Paper 53. University of Nebraska-Lincoln, Digital Commons. http://digitalcommons.unl.edu/physicsfuller/53

“Terry Rae Nygren." 2011. Scarlet (31 October). http://scarlet.unl.edu/index-p=10268.html 
ARTICLES COLLECTED AT

THE CENTENNIAL EDUCATION PROGRAM

FALL, 1980

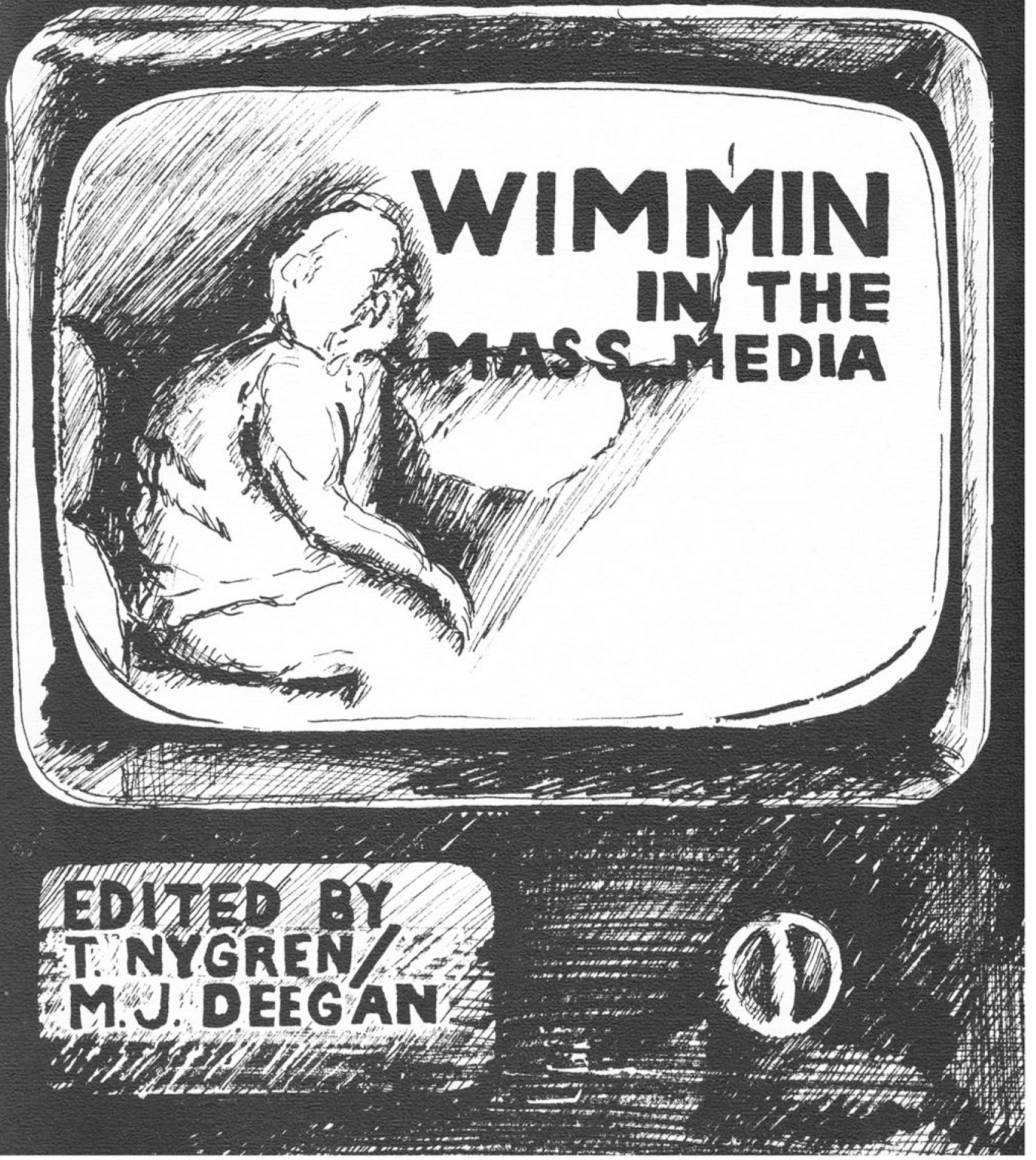



TABLE OF CONTENTS

PAGE

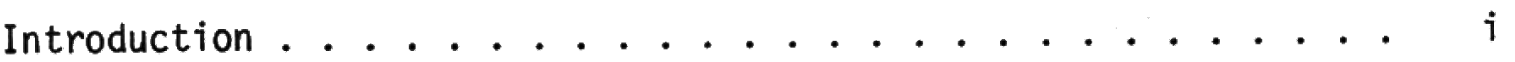

Mary Jo Deegan

Terry Nygren

Examining the Top Ten or Why Those Songs Make the Charts ............. 1 Jane Pemberton

Images of Women in Rock Music:

Analys is of B-52's and Black Rose ........... 11

Sheila M. Krueger

Women in Sitcoms: "I Love Lucy" . . . . . . . . . . . . 21 Nancy Grant-Colson

Horatio Alger is Alive and Well and

Masquerading as a Feminist or

Where are the Magazines for the Real

Working Women?

Teresa Holder

Freudian Tradition Versus Feminism

in Science Fiction ................ 41

Karen Keller

Typing done by Jane Mooberry

Cover Illustration by Becky Ross 



\section{WIMMIN AND THE MASS MEDIA: CONSTRUCTION OF THE SELF}

The work collected in this booklet was the result of an undergraduate course taught at the Centennial Education Program in the fall of 1980. The course was an extraordinary experience for students and teachers alike. The politics of feminism coupled with subject matter so omnipresent and influential as the media generated the interest and enthusiasm to support long hours of hard work. However, the core of this remarkable teaching-learning experience was the way in which the class came together as a group to provide structured support for both intellectual activity and emotional growth. We believe this was the result of not only a special interest in the subject matter, but was also heavily influenced by the particular structure of the course and the advantage of team-teaching and interdisciplinary work.

The course was designed to cover a broad range of media products: television, popular music, newspapers, film, magazines, and popular fiction. Our intention was to examine these products from a feminist point of view using several different theoretical approachs. The understanding and application of a variety of theories was vital to the project. We bel ieved that each theory would help to reveal a different facet of the media product, and that theory would help students to understand the patterns and relationships of forms of media in a larger context. We wanted to avoid the tendency to view each magazine article or each television program as a discreet and individual creation. While the wimmin in the class learned very quickly that theory is not that "magic key" to understanding students often hope instructors will provide, it did give them a way to begin, a particular angle, a point of view. At the same time students gained invaluable experience in manipulating abstract ideas by applying them to a concrete cultural experience. Finally, students became intimately involved in the excitement of the world of ideas, the excitement of inspiring each other to see their familiar world in a new way. This was education in its happiest form.

The class of twelve wimmin was team-taught by Mary Jo Deegan from Sociology and Terry Nygren from Film Studies. Each had previous experience in both Wimmin's Studies courses and popular culture, and each had a particular interest in theoretical problems.

The course was planned such that the process of learning the theory and learning to use it was simultaneous. Meeting for an hour and fifteen minutes two days a week, the first meeting was used to lecture on a particular theory and to deal with questions. The second meeting was primarily given over to student reports. Each student was required to observe a media product on a regular basis and to give a five-minute, in-class report every two weeks. This would be an analys is of that product from a particular theoretical perspective.

The oral reports served several functions. All students became accustomed to participating, to sharing their thoughts with classmates in a well organized, coherent fashion. Near the end of the semester, when presentations of final papers were required, most of the discomfort attached 
to speaking to the class had disappeared. Through the regular oral reports we also had an additional opportunity to monitor each student's progress in understanding the theoretical problems.

Each student was also required to keep a journal of reading notes. Three texts were used: Frame Analys is by Erving Goffman, Hearth and Home edited by Gaye Tuchman, and a reader compiled by the course instructors. This reader contained articles by Juliet Mitchell, Frederick Engels and Eli Zaretsky on Marxism and feminism, articles on Freud, on the concept of formula, on feminist film criticism, and a feminist analysis of the Harlequin Romance. The following is a summary of the theoretical approachs explored in the course.

\section{WIMMIN AND THE MASS MEDIA-- THEORETICAL ISSUES}

There is no one dominant theoretical perspective for interpreting wimmin's status in society. Therefore, a variety of possible interpretations may be used depending on one's perspective and view of everyday life. The creation and maintenance of each of these philosophically based options is presented briefly below.

MARXISM: Society is structured primarily through economic forces. Therefore, whoever controls the money and means of production (capital controlled by the bourgeoise) also controls the generation of ideas and images found in that society (hegemony). More precisely, men control capital and the mass media and the symbolic development of wimmin's role in society.

See Frederick Engels, The Origin of the Family, Private Property and the State

FEMINISM: Juliett Mitchell's approach to explaining wimmin's status is to define four inter-locking variables as systematically keeping wimmin oppressed in everyday life. These are production, reproduction, sexuality, and socialization. Through paid labor, myths surrounding the reproductive cycle and function, sexual roles and their support through symbols and the belief in romanticism, and the learning of appropriate sex-linked behaviors, wimmin are kept in a restricted social status.

See Juliett Mitchell, Woman's Estate.

FREUDIANISM: In this approach, human behavior is interpreted as a function of biologically based drives and capacities for action. Unconscious forces become attached (or cathected) to objects and these symbols thereby explaining and ordering a considerable portion of our behavior. Wimmin have biologically limited anatomies which they can partially transcend through the men they "love" and the children they bear.

See any of Freud's writings. They are explained, however, very succinctly by Daniel Yankelovich and William Barrett, Ego and Instinct.

STRUCTURALISM: There is a major school of thought which is written under this rubric, but we have focused on a particular American version which is less deterministic in its explanation of everyday behavior, that of Erving 
Goffman. In the latter's approach, society is governed by rules that organize experienced ("Frames"). Here, the status of wimmin is explained through the generation of sex linked rules for behavior.

See Erving Goffman, Frame Analysis.

MASS MEDIA ANALYSES: A series of articles specifically on wimmin have revealed their restrictions in different media within specific "formulas" popular in American social thought. A good example of these specific writings is found in Gaye Tuchman, Arlene Daniels, and Stephen Benet's Hearth and Home.

This additional summary of the use of Freud is offered here, not because his work was given particular emphasis in the course, but because many of the articles reproduced here use Freud in some way. We add this for the sake of clarity.

\section{FREUD - OEDIPAL COMPLEX AS DRAMATIC STRUCTURE}

Freud felt the Oedipal Complex was vital as it was the moment of confrontation between our physical urges and the social formation. Our sexua) identity in society depended upon how we resolved this confrontation. In our examination of popular culture we have found Freud's myth of the Oedipal Complex imbedded in these products as a dramatic structure. Regardiess of its truth value, Freud's description of the acquisition of sexual identity has been maintained in mass media as popular myth. The following is a summary of Freud's ideas.

\section{Basic Assumptions}

1. All infants assume there is only one sex, and that is male.

2. The idea of the phallus as an image and symbol is most powerful in our culture.

3. The mother is the first significant love object for both boys and girls.

4. The Oedipal Complex is fundamentally different for each sex.

\section{For the Boy}

1. As he enters the Oedipal phase the father looms as threat to boy's relation with mother.

2. This threat begins to focus on genitals (highly valued as prime source of infantile pleasure). Threat = castration anxiety.

3. Discovery of Mother's lack of penis, interprets as "Mother has been castrated." Brings castration anxiety to crisis.

4. Resolves confrontation by renouncing desire for mother, temporary acceptance of father as dominant.

5. Crisis and resolution brings sudden forced acquisition of super-ego (social conscience). Boy identifies with father as power figure.

For the Girl

1. Realization that she, like mother, is already castrated.

2. Repression of active desire for mother, shift of love object from mother to father. Identify with mother who is devalued. 
3. Sense of inferiority, lack of crisis and forced resolution means weak super-ego (faulty sense of right and wrong).

Boy is heir to the place of the father, the position of power and order. Girl is heir to secondary position within the social order. Her primary point of identification is symbolic lack of phallus.

As a narrative structure:

The male brings the narrative to crisis, confronts the threat, and resolves the story by over-coming obstacles, placing all story elements in their rightful position.

The female provokes the crisis (or acts as threat), and then becomes passive observer.

The work reproduced here represents only a portion of work completed for the course. Some students chose not to participate, even though their work was equally excellent. Students were neither pressured to participate nor denied access to the creation of this booklet. The class enjoyed additional papers on children's television programming, magazine and television advertising, a report on the "Cosmo Girl," and a film analysis.

\section{FEMINIST EDUCATION}

The success of the course, to a large degree, depended upon the very special setting provided by the Centennial Education Program. The freedom and flexibility of this program is vital to any future consideration of feminist teaching-learning situations. Because the situation and structure of a course is as important as content, we would like to share what we learned about teaching at Centennial.

\section{FEMINISM}

The belief that wimmin are equal to men and should have all opportunities in society open to them is a radical one. It is not based, however, on a desire to be like men in this society. Rather, it is based on the assumption that the present organization of society is intrinsically unfair; and that wimmin, in particular, suffer from such an organization of behavior. This arrangement is, in turn, based on a network of assumptions about the control of behavior, the nature of being male or female, or even of being an animal or plant. The organization of labor within the home and the marketplace, the socialization of children, the distribution of goods and services, control over the means of production and capital--all of these factors are criticized by feminists.

In the classroom, feminists see these same societal restrictions and assumptions about the world at work. Therefore, feminists are basically against the educational structure and institutions found in our society. These are the mechanisms that al ienate students from themselves, that instill a fear and envy of authority, and that control the distribution of goods and resources throughout their future careers, homes, and relationships. Thus, feminists in the classroom have a goal of teaching and learning that is antithetical to many of the assumptions about education 
operative within the larger university. Simultaneously, it is this same oppressive structure which allows them the freedom to create these alternative spaces and communicate with others so this duality is a basic one that must be confronted in the classroom and during the learning and teaching process.

\section{AUTHORITY AND LEARNING}

People concerned with learning are against most educational policies and procedures, for generally, most educational institutions and classrooms are designed to control the student, to reinforce the present authority structure in society, and to place students in hierarchical slots of achievement. Those that are "good" students are rewarded by "high" letter grades, and those that are "bad" are punished with "low" letter grades. Being considered "good" or "bad," however, is often based on overtly accepting authority, finding and taking courses, and surviving a bureaucratic system of organizing behavior.

Many "radical" professors are often seen as also being against "authority" and "rigid" assignments. Succinctly, they are thought to be "easy," too. Thus, they can be manipulated in the race for grades while having a veneer of being anti-establishment and "one of the students." They may be "popular."

Neither of these positions, however, are conducive to learning. Learning is a very difficult, often painful and inevitably exciting process. It involves changing one's way of looking at the world, expanding one's ability to see different perspectives, understanding views different from our own, analyzing our own knowledge, and learning how to read, write and speak well. All of these are challenges which never end. (We can improve but never be perfect.)

Thus, professors and students are "natural" opponents. The professor wants the students to engage in this exciting but painful process, and the student wants to either avoid it or fake it or, if given the strength and motivation to undertake it, do it successfully. Therefore, a teacher motivates, prods, punishes and rewards for visible evidence of learning. Although actual learning is a somewhat invisible and artistic undertaking, there are definite steps to set the groundwork for this achievement: hard work.

Truiy radical professors or teachers, then, expect their students to learn despite being in an environment that is not conducive to learning. They are often considered "hard" and "unsympathetic," they give "bad" grades (which are often an arbitrary rather than just punishment), they EXPECT their students to suffer and take this as a good sign. They think the students will be confused, have problems and be hostile. Simultaneously, such professors know that this is only a stage and not the end point.

Thus, teachers are, in fact, authority figures. It is responsible to accept this reality and to point out the difference in training, skills and knowledge that exists between them and students. Simultaneousiy, teachers do learn from students, are not superior beings, nor infallible. The 
student role is a shared one, but one that exists at different levels. These apparent hierarchical arrangements can be seen as multi-dimensional and continuous. Entry into different levels is not afforded by steps that coincide with grades or credentials. Instead, what evaluative differences emerge are due to the amount of work and learning that has occurred. Expertise in one area, moveover, is not assumed in all areas and differential rates of learning, interests in learning and subjects are inherent in each individual.

Thus, "good" teachers like "good" students do exist. Often these categories do not coincide with education criteria, and it is the ability to make these vital distinctions in evaluation which allow learning to occur.

\section{THE SETTING}

Classrooms, in general, are arranged to discourage communication but to encourage control by the authority figure. This is seen in their sterile environments: plain walls, tile floors, chairs in rows facing straight ahead, distances between the participants, and harsh lighting. These spatial factors enhance distance between the authority and the student; and the students themselves. Students are thus placed in a position of high visibility and management. They are isolated and often are seated while the instructor is standing.

Large classrooms have even more odious barriers to communication. Often most participants are anonymous to one another. Eye contact is difficult to make. There may be multiple exits and entrances. Microphones may be necessary to hear the authority speak, visual aids may be needed other than a blackboard, and even these may be difficult to decipher. Interruptions must be controlled rigidly because so many people could easily entirely disrupt a session.

Spaces that have more flexible seating arrangements, that have individuality, comfortable seats and floors, that have multiple aids such as blackboards, wall outlets, and video-equipment automatically establish the possibility for a range of authority relations. Flexible spaces allow informality and formality, and supportive teaching devices enhance learning. Therefore, learning and not control becomes the focus of such a class and the instructors and students do not have to battle the setting before they can even begin to communicate.

\section{INTERDISCIPLINARY TEACHING}

Almost all training in higher education consists of dividing up behavior, events or topics in such a way that a portion of it is analyzed from a specific perspective. These narrow foci are then utilized over a wide range of topics. Clearly, a specific and powerful mode of analysis emerges, emphasizing selective features of vastly different phenomena.

However, the opposite training is also needed: the ability to see events as whole entities, to bring several perspectives to bear on a given fact, and to integrate the disparate knowledge generated from various 
disciplines. This process of integration and analys is is very different than the "usual" discipline-linked training in which the professors and the students both suffer from a too specialized understanding of events. In order to provide this needed balance, a systematically different perspective, an interdisciplinary perspective, needs to be presented.

To teach daily with a person trained in another specialization is to receive consistent, immediate feedback on the differences in their view. This systematic variation can be revealed more clearly and in a variety of contexts and over a range of subjects. Rather than one formally presented interdisciplinary approach, this teaching style is a living integration of events that are mutually interesting to the presenters and audience. Not only do the presenters articulate their trained views but they build the necessary bridges to sharing these differences that are not provided by isolated sets of knowledge. This bridge-building, moreover, is often new to the teachers who have been trained to become experts in their areas and consider themselves amateurs in other areas, even those directly relevant to their topics of interest. Thus, the area of authority for specialists can be rapidly and greatly expanded due to their already advanced training and experience in a given field of study.

The students can actively observe the learning process of their instructors as well as be participants in their own integration and knowledge expansion. Thus, learning is a lived experience which generates its own creativity and curiosity, and it is difficult to create this active experience when only one person has authority and this power is based on only one major base of knowledge. By revealing differences and ignorance and partial knowledge and the process of filling in the gaps, the authorities in different disciplines illustrate and live the process of expanding their horizons. It also creates an environment where all participants are truly learners and where a massive imbalance in knowledge is more evenly distributed. The general benefits of team teaching, regardless of one's area of specialization, are discussed in greater depth below.

\section{TEAM TEACHING}

Having more than one teacher in a class radically changes the power structure. Authority, by being shared, is more visible as a created phenomena rather than a given. Disputes over inter-relation of a fact or the nature of the event under discussion actively reveals the process of interpretation or generating knowledge. Similarly, different interpretations can be meshed showing their common views as well as the gaps or barriers to understanding in this mutual perspective. Authority is also more easily challenged by a peer than by a student. Team teachers can, therefore, disagree with a presentation or idea from a systematic position. They can articulate why they perceive or define the topic differentiy. This strong and different basis for judging thereby makes the raising of questions and the intelligent voicing of differences an integral part of the learning process.

More than one voice of authority can provide a setting to offset errors in judgment or help carry a portion of the course when one of the teachers is not at his/her peak of training or stamina. Thus, the quality 
of teaching can remain evenly high over the entire course.

Handling criticisms raised from a peer can also actively demonstrate to the students the way to respond to criticism, either to correct one's position or to defend it and yet still remain open for future critiques. Succinctiy, team teachers teach each other and display this learning process to their students who then can learn how to learn: a very subtle but vital process that is often invisible and even beyond concrete articulation and must be a lived example.

Team teachers aid one another in the grading process as well. This painful component of structured education can be shared and this dramatically eases the process of decision-making as well as providing, again, an internal corrective mechanism. One of the most reassuring aspects of team grading is discovering siriilar judgments made independently or, the opposite, finding another perspective from which to evaluate a piece of writing or oral presentation. Thus, accountability for grading is a built-in component of team evaluations.

Each member of the group teaching the course becomes a viable, articulate, well-trained resource to illustrate the lectures of the other. Thus, one person may raise a topic and the other supply three or four examples from their own experience or training. This spontaneous sharing of experience and training creates a depth in delivery and information that is greater than an individual can provide. With a shared interest but differing backgrounds the pool of experience is generated in a multiplicative and not only cumulative manner.

Clearly in this situation, team teaching generates creativity. This ongoing sharing and building reduces the frequent isolation of teaching: having no colleagues with whom to discuss one's work, being isolated in the classroom as the authority, the isolated decision-making on evaluations, and the sometimes arid stretches of individual creativity and responsiveness.

Finally, classes can become very dry places, where students fear raising questions, dread coming to boring lectures, and feel alienated from the whole process of formal education. It can take many weeks of work before a class begins to get interested in the subject or trust the teacher. This whole distance from the classroom can be dramatically altered immediateiy. The team starts talking to each other immediately, they question each other, they are interested in the subject, they care about the ideas discussed and the way they are presented. This automatically removes a lot of the passivity of the classroom and the testing of teachers' tolerance and openness is displayed through their treatment of each other.

Team teaching, then, is an acting-out of the learning process and an alteration of previous authoritative structures which punish questioning and criticising the "professor." Similarly, the teachers are learning, too, and have an interested and articulate audience instead of passive containers who reluctantly ingest only the minimum amount of information needed to pass. 


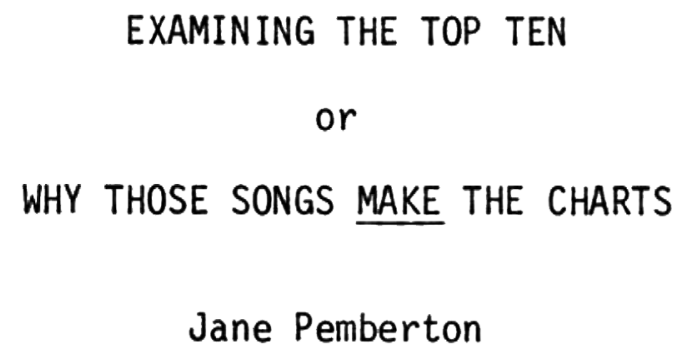


What is popular music? Is it the choice of a majority, the themes of the trendy or simply a grab bag of "hit songs?" I believe pop music, or 'top forty' serves to perpetuate a specificideology and is popularized, with few exceptions, on this basis. We may first hear this music on the radio, perhaps in the concert hall and eventually diluted to faint recognition in the "Muzak" of the dentists' office. All but the careful listener will absorb most of this music unconsciously. Nonetheless, the lyrics reflect our society, be it through new wave monotone, country twang or operatic virtuoso. The ideology is the same in all because it stems from the same power structure, the same political and economic conditions. Since the dominant ideology of a culture will be that of its ruling class, ours is a bourgeois ideology. This ideology, so deeply ingrained as to seem invisible, embraces private property, competition, an artificial public/private split, romantic heterosexual love, monogamy and devaluation of women in general. As we shall see, our popular music is determined by and mirrors this ideology.

In the sixties, many aspects of the dominant ideology were challenged. Communal living was popular, monogamy was criticized, a distrust for the "establishment" flowered and the police, maintainers of bourgeois law and order, were dubbed 'pigs.' This was not just an experiment in "turning on, tuning in and dropping out." The movement had a revolutionary potential. Black Panthers took up arms and studied the Chinese revolution, buildings were blown up, and thousands of college students supported the Vietnamese in their struggle against American imperialism. From this fertile ground sprang the Womens' Liberation Movement. Despite the prevalence of progressive attitudes, the liberation of women was often viewed by the left as a twisted self-indulgence. Women were booed off the stages of demonstrations and used as rewards for draft evaders in slogans like "girls say 'yes' to boys who say 'no'." It seemed that middle class men on the left were willing to experience oppression as 'hippies' as long as they could continue to oppress women.

The so-called "cultural revolution" of the nineteen sixties was epitomized by rock music. The woodstock nation did little to change the position of women in its new society, as Marion Meade describes:

"Sweaty, bearded men were busy building the stage, directing traffic, shooting the film, and running the festival. Brotherhood was repeatedly proclaimed, both on stage and off. Woodstock Nation was beginning to look ominously like a fantasyland which only welcomed men." I

The Rolling Stones sang about a woman's proper place - "doncha think there's a place for you, in between the sheets?"2 Cultural? Yes, maybe. Revolution? No.

The tradition of men in music was certainly not a new one; it had only changed form. There were a few women who formed bands, Fanny and The Deadly Nightshade, for example, but they could not get jobs or good publicity. When they did find work the pay was a fraction of their male 
counterparts' or they were expected to 'show a little leg.' One promoter's comments are exemplary. "All chick rock group? Not interested. Too temperamental, you can't put any money on it. If they break up, who do you replace them with?" 3 Nothing had changed and the dominant ideology continued to broadcast its message like a mantra: Women are love objects.

Like the anti-war movement itself, the Women's Liberation Movement spanned across a wide political spectrum. Women involved in leftist politics tended to apply a Marxist analysis to the problem. They identified women's oppression as the first class oppression. "Women as Class" was a useful concept. Women could identify with other oppressed classes, blacks, chicanos and workers. Their condition was viewed as a product of the economic exploitation of capitalism. These feminists believed that a socialist revolution would bring the liberation of women. They felt that men were not the oppressors but named the capitalist system as the cause of their position in society. Another point of view came from the Radical Feminists. These women defined the oppressor as the entire male sex, pointing out the privilege that they enjoy in every economic class. Their concept of 'patriarchy' was applied to describe a global condition. They pointed to male supremacy in socialist societies as evidence that socialism would not lead to liberation of women. The physiological sexual differences of reproduction were put forth as a source of woman's status. "Hence the revolution is not just against a specific historical form of society (e.g. capitalism) but against Nature ..." 4 Radical Feminism emphasized the psychological and ideological oppression of women, whereas the socialist women pointed to economic oppression.

Juliet Mitchell addressed this question in articles as early as 1966 and in more depth in Woman's Estate in 1971. She disputes the polarity of the two views . . "if isolated, both end up, at the same point, succumbing to the chief tenets of bourgeois thought; empiricism and idealism. Radical feminism makes a 'theory' of the concrete experience of oppression, and those we might call 'abstract socialists' evade the specific oppression of women and idealize the role of the oppressed." 5 The result is a concept of women's position which encompasses four forms of oppression: production, sexuality, reproduction, and socialization of children. Characteristic of bourgeois ideology is the split within an individual or the family unit between the public or marketplace and the private realm or home. Acknowledging these separate realms of production and family, Mitchell identifies socialization, sexuality and reproduction as a 'triptych' of the oppressive forces comprising the family. In terms of popular music, I will use Mitchell's analysis to examine the role of women in its production and the oppression of women's sexuality in its lyrical content. George Gerbner states that "the main function of culture is to cultivate resistance to change." 6 Therefore, by examining culture, we can see how change is prevented despite the appearance of new images in the media. We can illustrate how the dominant culture is maintained.

Popular radio seems to revolve around the concept of 'romantic love.' This is the product that is perpetually being sold on the radio. This institution emerged in the twelfth century in opposition to legal marital forms. It has been used in more recent eras to justify the position of women in society, as wives to men and defined by relationships to them. 
Mitchell points out "there is a formal contradiction between the voluntary contractual character of 'marriage' and the spontaneous uncontrollable character of 'love' - the passion that is celebrated precisely for its involuntary force."7 The idea that it can be contracted for a lifetime conflicts with our very definition of love. Nonetheless these two concepts of 'forever' and 'love' are bound together in marriage. The Pointer Sisters sing "... I'll love until the day I die..."8 We know they are singing about marriage. As Marx said, marriage is 'incontestably a form of exclusive private property, "illustrating the roots of marriage in bourgeois ideology. 9 The fact that marriage rates remain relatively constant despite a fifty percent divorce rate and the rise in so-called premarital sex seems to support the dominance of this marriage-cult ideology.

Mitchell names sexuality as the 'weak link in the chain.' Because of increased sexual freedom, women are challenging their oppression in the realm of the family. This is possible largely because of contraception. Improved birth control has freed women from their previously inevitable role as mothers and it disassociates the classical justification for marriage, namely paternity. Alternatively, the forces behind the current acceleration of sexual freedom may have been only an aspect of a new consumption-and-fun ethos, presumably replacing the work ethic. Sexual activity has increased women's social freedom but she may pay in increased exploitation as a sexual object.

The aspect of sexual exploitation is germaine to the portrayal of women in 'top forty' Tyrics. This particular genre of music is targeted for teenagers and young adults. This age group is coping with questions of sexuality, mating and marriage. Teenage sexual activity has definitely increased. Statistics show that nearly fifty percent of the nation's 10.3 million women aged 15-19 have had 'pre-marital' sex.10 This is double the percentage since the 1971 study. Images of teenage sexuality abound in the media. In advertising, the youth market is a major target and young women are used to sell a variety of goods. In films the summer of 1980 , loss of virginity was a theme in three top shows. I found sexuality to be a recurring theme in top forty music also.

I surveyed a six-week period from August 2 to September 13, 1980. The top ten songs from Billboard's "Hot 100" were analyzed. I looked at race, sex and type of act. Song titles containing the word 'love' were counted as were those songs determined to refer to courtship, romance or love relationships. Additionally, the lyrical content of top ten songs was reviewed for the weeks of November 9 and 16, 1980. I will be elaborating on the content of some of these songs.

In the six-week period, a total of ten new songs were introduced, resulting in a total of twenty songs and twenty performers or groups. Two songs remained on the top ten for all six weeks. They were 'Emotional Rescue' by the Rolling Stones and 'Sailing' by Christopher Cross. Blacks performed an average of twenty-one percent of the songs. Soloist Diana Ross accounted for $38 \%$ of this total, another $38 \%$ came from male groups the Spinners and the Manhattans while $23 \%$ was due to singer George Benson. Women vocalists made up $26 \%$ of the artists on the top ten. All were solo artists. Diana Ross accounted for $37 \%$ of this representation, while the 
other $69 \%$ was divided among 01 ivia Newton-John, Irene Cara and Kim Carnes. The November top forty count down included 11 female soloists, 19 male soloists, one female group (The Pointer Sisters) and nine male groups.

The soloist statistics point to an emphasis on individuality and personal success for women. Males, it implies, can succeed either way, alone or in a group. A separation of women by the family structure, has prevented them from grouping. This individualistic message is carried through lyrics of songs which are performed by a group of singers but sung in the singular. Even the Pointer Sisters, who are our exception, sing 'He's so shy' from the first person, which is the only way it could be sung, since the conquest the song unfolds could not have been achieved by the three women. This tradition is not unique to female singers, but any other style is uncommon for them, though not for the male rock band. Diana Ross' 'I'm coming out' is done with background singers singing, in chorus, 'I'm coming out.' In both these cases the individual experience is emphasized.

This isolated image is coupled with the 'rising star' myth. The female vocalist is 'discovered' perhaps belting out gospel in the church choir (an amazing number of black singers sang gospel), or singing backup for someone else. Like a fruit on the tree, she is plucked by some clever promoter and subsequently made rich and famous, or so the myth goes. We see this idea played out in the many film versions of A Star is Born. The lack of instrumental talent (or the lack of its display), Teads to a sense of the singer's vocal talent as an innate quality. Her voice and her songs are meshed into an image. She is perceived as a variation on a theme of womanhood, rather than the way the male musician with guitar is viewed as artist. "Even an excellent guitarist like Bonnie Raitt was convinced to forego playing guitar tracks on her own album."1l Her talents should not go beyond those which absolutely require a woman.

We see the singer and hear her at her work in her productive role. Her work is hard. The competition is fierce, the hours long and physically straining. Women in the industry must endure sexism from condescension to outright sabotage. She is protected from the opportunities to master the necessary technology for her field, leaving her isolated and dependent. Mitchell says of women working, that "their exploitation is invisible behind an ideology that masks the fact that they work at all. Their work appears inessential." 72 Watching the vocalist at work, we are tricked into believing it is easy, it is innate, it is simply who she is.

The dominance of whites in our society is reflected in the top forty charts. Traditions of racism hold firm in popular music and its stars. Despite the fact that the music field is one in which blacks can succeed tremendousiy, there are specific formulas which govern their chances. The average female black performer is a solo vocalist. She does not play an instrument on stage and she is often dressed in the latest fashion. Physically, she could be a model, beautiful, white-ish features, thin and statuesque. Donna Summer, Diana Ross and the Pointer Sisters, who are currently on the charts, are examples. Joan Armatrading and Phoebe Snow are examples of black women who are not on the charts. Like all female vocalists, they sing songs of love. Sometimes black women sing songs of 
righteousness - Gloria Gaynors" "I Will Survive" and Aretha Franklin's "Respect." Finally, these women, along with the mass of black performers, do not sing about their unique experience as black people. If they do, they fail to make the charts.

One notable exception is Jamaican Reggae music. The untouchable Stevie Wonder's new hit "Master Blaster" is a good example of this style performed by an American artist. Its presence on the chart is an exception to popular music's apolitical limitations. Traditionally Jamaican music, Reggae embraces the politics and the rastafarian religion of the island. It speaks in tones of resistance, "get up, stand up, stand up, for your rights, don't give up the fight." 13 Yet its unmistakable beat is all we end up hearing in this country. This musical style extends far beyond the limited scope of its Jamaican roots. The telltale horns and beat can be heard in a recent pop song by Paul Simon and many other new but less blatent songs.

In the six-week survey of top ten charts, many references to love were found lyrically. Twenty percent of the song titles contained the word "love" - "Al1 Out of Love," "More Love," "Let My Love Open the Door" and "Looking for Love." Out of a total of 20 songs, 17 or $85 \%$ dealt with love or romance. In the November sample, $30 \%$ of the song titles included the word "love" and 70\% concerned love or romance. Equal percentages of men and women sang on the topic (75\% in both cases). Yet the male pool included 16 songs and the female pool only four.

There seem to be murmurings of response to the 'new sexuality' in the lyrics analyzed. An example is the Doobie Brothers' aptly titled song, 'Real Love,' the singer seems to long for the old days before sexual freedom. The sex is overt.

Darling I know/ I'm just another head on your pillow/ if only just tonight/ let me hear you lie just a little/ tell me I'm the only man/ that you really loved/ honey take me back to my memory.

The image is one of hardened singles, fantasizing about REAL LOVE in their unsatisfactory one night stand. The message is one of the woman adjusting her experience at the request of her partner. Lying is presumably a skill of hers. And who would say no to love? Maybe it is an avowal of love itself. It is an interesting role reversal, woman interested in sex, man in love. The sympathy lies with the male perspective.

Hall and Oates are singing 'You've lost that loving feeling' at number 13 while Cliff Richard is 'Dreamin' at 11. Dreamin is yet another example of the dissatisfied man. He is up all night walking around, "that's the time I always think of you' he sings to the woman whom he admires from afar.

"five o'clock, still walking around/ I call you up but you just bring me down/ . . . . I guess you'd say I'm getting nowhere/ but in my dreams you always come around/ here am I/ I'm taking a chance/ I'm walking on air/ flying so high/ facing the truth there's no other way I'll make you mine." 
The image is one of frustrated sexuality and there are suggestions of masturbation as an outlet. The image of the invisible female in this song contributes to her sexual objectification. Her only act is to 'bring him down' a subtle sexual image in itself. The rest of the song is about the singer. The message is, "it will have to be a 'dream' for anything to happen between him and the woman." The images of dreaming and perhaps wet dreams are suggested.

Similarly, Devo's "Whip It" suggests the listener 'whip it' - "when a problem comes along" or "when a good thing comes along" or "when nothing's going wrong" all to a driving beat. Again the slang phrase 'whip it out' may be pertinent. The masturbation theme might be a response to the heightened sexual pressure for teens. It must be reassuring to hear that your solution is not a 'cop-out.' In accordance with an ideology which denies female sexual pleasure, we find no such songs clearly directed to female masturbation. This phenomenon may also stem from a reaction to female sexuality; again perhaps a longing for the old days when the only orgasm that mattered was the male's.

Women continue to sing in praise of their abuse. Three examples currently on the chart are Diana Ross' "Upside Down," Carly Simon's "Jessie" and Barbara Streisand's "Woman in Love." Mitcheil addressed the question of the oppressed reflecting the ideology of the oppressor this way - "All oppressed groups - workers, women, colonized - can have their oppressed consciousness, but the ideology they propagate must be either that that is dominant in the society that oppresses them (bourgeois ideology), or that that they have consciously espoused for the society that will overthrown this." 14 The contrast is great between Barbara Streisand singing "I am a woman in love/ and I'll do any thing/ to get you into my life/ and hold you within/ it's a right I defend," and Holly Near, a feminist singer/ songwriter, singing "Nicolia, a girl, worked inside a factory/ she never saw the sun and she never felt the summer breeze/ she dreamed someday she'd meet her prince but she's been real disappointed since/ Nicolia a girl got a big idea somehow and she's sailing, sailing now." The ideology behind "Woman in Love" seeks to make narrow the options for women. The song is put forth as the definitive description of a woman's response to love, including the lines - 'I turn away from the wall/ I stumble and fall/ but I give you my all.' Near, on the other hand, sings to us of a girl, trapped in a factory, who 'sails away' through organizing her fellow workers. She is expanding our horizons as she sings of Nicolia's growth.

Ross'. "Upside Down" also sings a song of stagnation. "I cherish the moments with you/ respectfully, I say to thee/ I'm aware that you're cheating/ but no one makes me feel like you do/... I'm crazy to think you're all mine/ as long as the sun/ continues to shine/ there's a place in my heart for you/ that's the bottom line." The promise of forever, and it's implications of marriage are like a deed to "a place in my heart." The problem is not so much that Diana's fellow is 'cheating' but the song's reverence for a double standard.

Carly Simon's "Jessie" goes beyond this and wallows in a classic female masochism in the best traditions of Bessie Smith and Janis Joplin. She tells us 'he cut up my heart like a paper doll' and he 'set me up 
just to let me fall.' Despite the warnings of her mother and friends, who will think she has 'sunk so low,' she is persuaded by her heart ('with a will of its own') to see him. These images of female support are not accidental. The mother and women friends are a source of encouragement for the singer's struggle for independence. These women are like a metaphor for the power of sisterhood and Carly Simon gets rich renouncing it for an abusive heterosexual relationship.

The Pointer Sisters' latest hit, 'He's So Shy,' tells the story of the singers' approach in seducing a shy man. It tells of overcoming her fear and then aggressively pursuing the mute fellow. "I longed to speak but did not dare/ something inside whispered to me/ you better move in carefully." She knows he is interested when he looks away from her gaze. This song is reminiscent of the Harlequin Romance formula in which the mysterious, nonverbal male ("he's so good looking') turns out to be secretly in love with the heroine ("and he's got me going"). The man is repeatedly referred to as "that sweet little boy who caught my eye." The iyrics speak to the question of aggression in women, in an affirmative way. The image is that of the experienced, older woman and the shy young boy, a common sexual fantasy. The message is one of reassurance to the insecure, bumbling teenager. It seems to be saying "someone can find you attractive by virtue of your unmanly qualities." One line goes "each time I see, that quality it never stops attracting me." The image of the Pointer Sisters being attracted to a fellow because he doesn't say a word must be appealing and clearly it sells. They assure us that this love will last "until the day I die," and again we see the theme of pairing for life.

'The Wanderer' is a very successful release by Donna Summer; it is currently number three in the top ten. The song is a first person assertion of independence. The wanderer has quit her nine-to-five job and now travels everyplace, 'from here to outer space.' The wanderer is a roamer but not a loner. "Don't have to worry cuz I seldom am alone." The problem with this image is that it conflicts with reality. Women cannot travel safely alone, at least they cannot live on the road. Nonetheless, it is a positive, unconventional image for a woman.

The number one song in the nation the week of November 16 was titled, simply, "Lady" by Kenny Rogers. (This song dispells any doubts that the more things change the more they stay the same.) "Lady" is a plea, an ode, a tribute. The general tone is one of chivalry, and courtly love. "Lady, I'm your knight in shining armour and I love you/ you have made me what I am and I am yours." The song continues in this rather heavy-handed fashion as Rogers proclaims his undying love for his 'Lady.' The song is almost a desparate one, riddled with every romantic cliche he could fit in. "We belong together/ for so many years I felt I'd never find you/ you have come into my life and made me whole/ let me wait to see you each morning/ let me hear you whisper softly in my ear/ in my eyes there's no one else but you/ there is no other love like ours/ I'll always want you near me." This appears to be the "Real Love" the Doobie Brothers are speaking of. This straight-out romanticism seems incongruent with the majority of songs on the charts which get the message across in slang and double meanings. The message is, of course, the same. The same plans for a life-long love and the same possessive pronouns. These are not conventions but have a 
basis in fact. Marriage means a transfer of property, sometimes a merger. The property aspects of marriage do not disappear in the working class either. Though the restrictions of property do not dictate their choice of partners, the legalities of marriage dissolve personal property rights of women, generaliy maintaining those of men.

Aside from some assertiveness and independence by women, there is no real challenge to the dominant culture posed by the 'best' of the top forty lot. The underlying assumptions are consistent. Heterosexual images are the only ones permissable. Marriage or life-long commitment is the ultimate relationship to strive for. Monogamy is the only functional mode for relating, people feel cheated and possessive otherwise. We should view partners as possessions and women as beauty objects. The work of women is insignificant and their skills are actually innate, god-given qualities. Economics are not factors affecting one's day-to-day life or relationships. These are a few of the underlying assumptions of the bourgeois ideology and, as we have seen, they hold true for top ten music and the music industry. The vast majority of images of women in the media coincide with what we have found in top forty radio because, despite a multifaceted culture, we have a unified ideology with little tolerance for variance.

Mass media can be deceptive. Things change so rapidly on the television screen, on the newsstand, at the theater and, of course, in music. The constant influx of new images in the media, each picking up on the last trend leads us to believe we live in a changing society. Yet in the United States the power structure remains as firmly entrenched as its ideology. We will find true change in these cultural images only when this ideology and its basis are changed. I believe we will know these new images as something other than a new trend, for they will celebrate women and not degrade them. 
Footnotes

1. Marion Meade, The Degradation of Women, p. 173, from Sound of Social Change.

2. Rolling Stones "Live with Me" from Let It Bleed.

3. Aida Pavletich, Rock-A-Bye, Baby, p. 139.

4. Jul iet Mitchell, Woman's Estate, p. 87.

5. Ibid, p. 94 .

6. Gaye Tuchman, Hearth and Home; Images of Women in the Mass Media, p. 47.

7. Jul iet Mitchell, op. cit., p. 114 .

8. Pointer Sisters, "He's So Shy."

9. Jul iet Mitchel1, op. cit., p. 110 .

10. Newsweek, Sept. 1, 1980, p. 48.

11. Aida Pavletich, op. cit., p. 139.

12. Juliet Mitchel1, op. cit., p. 139.

13. Bob Marley and the Wailers, "Get Up, Stand Up" from Natty Dread.

14. Jul iet Mitchell, op. cit., p. 96. 
IMAGES OF WOMEN IN ROCK MUSIC ANALYSIS OF B-52'S AND BLACK ROSE

Sheila M. Krueger 
"Rock is the surest way to the hearts and wallets of millions of Americans between 8 and 35--the richest, most extravagant children in the history of the masses."

The rock industry is a booming one. In 1972, $\$ 2$ billion in records and tapes were sold in the U.S. alone. 2 Rock themes have permeated law firms, clothing manufacturers, the mass media, soft drink companies and car dealers.

The impact of rock music on women is an area not widely studied, but which is fast becoming an important issue in the feminist arena as the role of mass media in socialization becomes clearer. The messages that are received by the listener are repeatedly sexist and sometimes even anti-woman in language. When we consider the fact that children are drawn into the rock cult at a very early age (8-10), it becomes clear that these messages are more than likely to be entertained as reality.

"For young people in the cities, the topical songs have become abstract emotional substitutes for what is going on in the world; and although this can be a good factor when it stimulates people to action, more often it is a delusion." 3

Juliet Mitchell states that the pyramid of discrimination rests in a very solid foundation--education. I believe this foundation also includes the mass media, and therefore rock music, an area of popular culture which cannot be overlooked. Mitchell also reasons that it is the function of ideology to present given social types of women as Nature itself. 4 Musical messages make sexism seem a natural, right thing.

The function of a sexist ideology is to provide a host of subtle practices which are effective in keeping women in their place. The key here is the word subtle. Who would suspect music as a primary source of socialization? We find out there are many.

"If the music was not so relentlessly innocent, it would be hauled into court as the ultimate evidence of youthful degeneracy." 5

The evidence that music influences the minds of young adults, and actually the population in general, is overwhelming, and not a phenomena which has only recently been discovered. Plato's Republic is quoted in American Opinion:

". . . the introduction of a new kind of music must be shunned as imperiling the whole State, since styles of music are never disturbed without affecting the most important political institutions. " 6

Dr. Joseph Crow, an expert of musical subversion, gives us some insight on the method that rock employs to slide the message into home base. 
"By changing the rhythm within a musical piece, you can have a strong impact on the listener... the subliminal effect is to push the 'message' much more strongly. Some people actually have a physiological response when, for instance, a beat is switched from $3 / 4$ time to 5/4 time. Pop music now does this type of poly-rhythms all the time, because it accentuates the message. We were taught never to do this in music school, but we were not trying to use music for mind conditioning." 7

All of this evidence points to the fact that the rock music message does make an impact on the socialization of people in our society.

I turn now to two musical groups which are fast becoming popular in the music world. The B-52's and Black Rose are actually classified as New Wave. However, both bands have their origins in rock. The lead vocalist for Black Rose is Cher, who has traveled the musical road from bubblegum rock to New Wave.

The B-52's, named for the bouffant hair styles of the female members, are comprised of two women and three men. Their first album was hailed by Ms. magazine as being "sexism free starkraving-sane combination of offthe-wall and right on!" 8 I don't believe the "wimmin" at Ms. would be as thrilled about their second album 'Wild Planet,' as the songs included are not exceptionaliy flattering to women.

The first album, 'The B-52's,' is not unbiased when it comes to women. In the song "Lava," sex is discussed as a violent thing, with lava symbolizing the male ejaculate, a bomb which sizzles and burns. The male partner knocks his partner in the head and kicks her into bed. The woman is trying to romaticize their love during the song, while the male only knocks her down and sleeps with her. She seems to want to continue sleeping with her man, even though he is breaking her heart.

"Hero Worship" deals with a groupie that has devoted her life to idolizing her hero. She discovers during the song that he is not really all that wonderful because he does not return the devotion she feels she deserves. She tells us "heroes falling to the ground, like hell's magnet, pulling me down..." She feels like she is being dragged down by her unreturned devotion.

She realizes that even sex is useless to bring devotion and seems to despise the implications of sex, or as she describes it, "jerking motions won't revive him, mouth to mouth resuscitation."10

She sees the man behind the myth as she looks closely and sees, "Motor, motor, broken-hearted, rusted, rotted, falling apart, a lock of hair, a belt he wore, it's not enough, I NEED MORE." 11

The second B-52's album, Wild Planet, is so blatantly sexist that feminists should be very alarmed. The song that is the most destructive and disarming is "Quiche Lorraine." In this song a woman is portrayed as a bad dog, a two-inch, green poodle with a strawberry blond fall. 




It is very obvious from these lyrics that the B-52's are not as feminist as Ms. would have liked them to be.

The female is portrayed as an obedient love object, to be admired and trained to do what her master desires. Even when the dog (woman) leaves, she does not leave to be independent, but rather, goes to another man (great dane).

The male becomes first upset, then frustrated, and finally bitter and 
vindictive towards the poodle. He tries to talk himself out of missing her by going over her physical attributes and finding things that seem undesirable or artificial in our minds, e.g. the strawberry blond fall.

The male who sings the song seems to feel that this doggy was only around to have a good time with, and to do her duty for him, by barking and shouting. When she quits doing her duty, she loses his love and, as the audience is told, will not be allowed to return.

He feels that Quiche Lorraine has been rotten to him, not taking into account the fact that Quiche Lorraine has been living her very life for him and has never been by herself.

The song "Dirty Back Road" again uses symbols for males and females.

\author{
Reckless driving like a sports car \\ God I want you like a fuel \\ Engine energized line \\ Like a road you ride me \\ Foot on the pedal \\ Feet in the air \\ Sand in my hair \\ Oh don't look back \\ Don't look behind you \\ Reckless driving on \\ Dirty back road. 13
}

The male is seen as a sports car whose fuel (ejaculate) keeps the female going. The female is the road on which the sports car drives. Sex seems to take on the aspect of being unclean as this refueling act takes place on a 'Dirty Back Road,' in which, if the analogy is carried out further, the female is the dirty back road on which the sports car is recklessly driving. So not only is sex dirty, but this guy is lousy in bed and our female loves it! Why does she do it?

The image one would receive would seem to say that women enjoy being degraded and used as sexual toys. She cannot survive without sex and she likes it as dirty as it comes. The very use of dirty 'back' road implies anal intercourse.

While the covers of the B-52 albums are harmless enough, showing pictures of the group together without a background, using only color, the cover of the Black Rose album is revolting. Done in purple and black, the cover depicts a female set of feet with spiked heels, fish net stockings and a black rose tattooed on the left ankle. The ankle also has wrapped around it two circles of thorns.

"Take It From the Boys" is a song about sexual harrassment and Black Rose's solution is to quit your job and hit the streets as a hooker, simply because that way you don't have to be so prim and proper.

So scared I've never been

Too hard to keep it in

Good girl, independent citizen 
But you can't go back, no they' 11 never let you back

Same dance, different hall

Some guys they get it all

But you can't go back and they're ready to attack,

And you can't go back and you're terrified you're gonna fall.

Take it from the boys in the street

Take it from the boys.

Take it from the boys that you meet makin' all that noise

They've got you sippin on a dry martini on their lap

Slippin out the back door, no slacks.

Baby it's the same with every man you meet

You might as well be wise and take it from the boys in the street.

Do this and promise that

That's how they all got fat.

Watch out you're dealing with a photostat

When they say they care it's a bona fide affair

Look out beware the business man

Express American

He'jl be gone so fast, cuz he travels first class

With his powie powie stash

And his heart of artificial glass

Take it from the boys in the street

Take it from the boys.

Take it from the boys that you meet makin' all that noise

They've got you sippin on a dry martini on their lap

Slippin out the back door, no slacks.

Baby it's the same with every man you meet

You might as well be wise and take it from the boys in the street. ${ }^{14}$

Cher begins by telling us she is scared for her job and she has to tell somebody about it. She says she's been a good girl, an independent citizen, but she got caught in a trap and there's no way she can go back to being a good girl again. She realizes that the same dance implies that sex for profit is just occurring in some place nice instead of a sleazy motel and that these guys have the bucks to keep it that way. You have to give in or lose your job so you might as well take it easy and hit the streets as a hooker. Sure you did fun things, but you had to be nice, dress up and sneak around a lot and it's just a drag. She views the business men as phonies, a bunch of copies of each other with artificial glass hearts. He'll promise all sorts of things, but don't believe him because he can leave at the drop of a hat, because he's got credit and the credentials to do it.

This song tries to tell us that basically women are lazy sleazy hookers who will do it with anybody, and if they get paid, that is just so much better. The aspect of rape cannot be overlooked either. It would seem that her initiation into sexual harassment was perhaps forced.

"We All Fly Home" is the message of a married woman to an independent woman. 


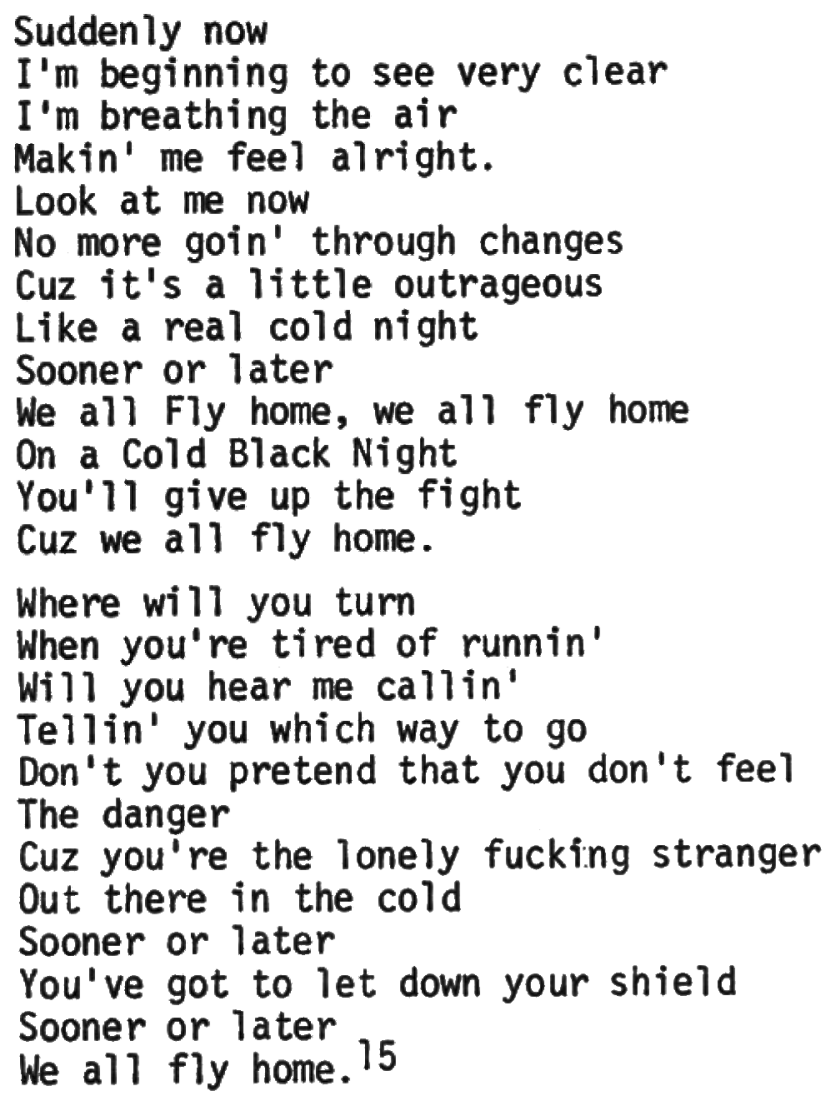

Marriage seems to have made this woman realize that her independent stage of development was a waste of time. Now she tries to tell her friend not to make the same mistake. The married lady is upset because her friend is hard and won't let down her shield, which is protecting, but cold, not like a good man. These ideas of independence are pictured as cold throughout the song. The life of independence is outrageous because there is no man to keep you protected and warm.

The married lady seems to feel it is easier to breathe (grow as a person) now that she is married. However, it would seem that the high divorce rate in the U.S. shows that women are getting out of relationships that are the opposite, that is, rather suffocating types of relationships.

She sees the role of wife and mother as a duty, and is looking forward to the day when her friend takes up her responsibility also. As far as the married lady is concerned, this woman is only a stranger who is by herself in the cold world of independence, a world which will not allow men in, so you are either independent or you have a man, similar to being unable to combine marriage and career.

This song points out very strongly the role of socialization by women, one of the four structure roles in which women are involved. Mitchell sets out these structures for us in Woman's Estate. The structures are: production, reproduction, sexuality, and socialization. 16

The role of women in production is totally ignored in the songs which I have analyzed. The secretary doesn't do any work and she is the only 
woman we know to have a job. It is not known how the groupie of "Hero Worship" makes money to support her idolization.

The role of the married lady in "We All Fly Home" is the only view of socialization and reproduction that we are given.

Sexuality is the role in which females are most apparently available or in which they are highly accessible. All of the women in these songs appear to be easily available, except for the independent woman who is withholding her sexuality for a career.

The messages that are received about women in these songs are certainly not the type of message we would want portrayed to, or learned by the consumers of pop culture.

The rock culture is most definitely reaching our youth and teaching them that women are sexual toys and tramps. This type of socialization, combined with that of religion, education, peer groups and parents, is the reason that women have been held in contempt and therefore submission for too many years. Until the messages are changed, the song will remain the same. 


\section{Footnotes}

1. David C. Birch and Fredric Rissover, Mass Media and the Popular Arts, Second Edition, (New York: McGraw Hi17, 1971), p. 286.

2. David C. Birch and Fredric Rissover, Mass Media and the Popular Arts, Second Edition, (New York: McGraw Hi17, 1972), p. 416.

3. Birch and Rissover, First Edition, p. 260.

4. Juliet Mitchell, "Women: The Longest Revolution," in Image of Women in Mass Media, ed. Mary Jo Deegan and Terry Nygren, (Lincoln: Kinko's, 1980), n.p.

5. Albert Coldman, Freakshow (New York: H. Wolff, 1971), p. 140.

6. Plato, "Republic" in American Opinion, February, 1969, p. 51.

7. R. Serge Dennisoff and Richard A. Peterson, The Sounds of Social Change (Chicago: Rand McNally and Co., 1972), p. 162.

8. Pamela Brandt, "The New Woman Sound Hits the Charts," Ms., September, 1980, p. 95.

9. B-52's, "Hero Worship," B-52's, Warner Bros., Inc., BSK3355, 1979.

10. Ibid.

11. Ibid.

12. B-52's, "Quiche Lorraine," Wild Planet, Warner Bros., Inc., BSK347l, 1980.

13. B-52's, "Dirty Back Road," Wild Planet, Warner Bros., Inc., BSK3471, 1980.

14. Black Rose, "Take it from the Boys," Black Rose, Casablanca, NBLP7234, 1980.

15. Black Rose, "We All Fly Home," Black Rose, Casablanca, NBLP7234, 1980.

16. Jul iet Mitchell, Women's Estate, (New York: Random House, Inc., 1971), p. 170. 
Bibl iography

B-52's. B-52's. Warner Bros., BSK3355, 1979.

B-52's. Wild Planet. Warner Bros., BSK3471, 1980.

Birch, David C. and Rissover, Fredric. Mass Media and the Popular Arts. Second edition, New York: McGraw Hill, 1972.

Birch, David C. and Rissover, Fredric. Mass Media and the Popular Arts. Second edition, New York: McGraw Hil T, 1972.

Black Rose. Black Rose. Casablanca, NBLP7234, 1980.

Brandt, Pamela. "The New Woman Sound Hits the Charts." Ms., September, 1980, pp. 66-7, 88, 94 .

Dennisoff, R. Serge and Peterson, Richard A. The Sounds of Social Change. Chicago: Rand McNally and Co., 1972.

Goldman, Albert. Freakshow. New York: H. Wolff, 1971.

Mitchel1, Juliet. "Women: The Longest Revolution." In Image of Women in Mass Media. Ed. Mary Jo Deegan and Terry Nygren. Lincoln: Kinko's, 1980.

Plato. "Republic," in American Opinion, February, 1969, p. 51. 
WOMEN IN SITCOMS: "I LOVE LUCY"

Nancy Grant-Colson 


\section{Introduction}

I chose to examine, during the 1950 's, the images of women in the situation comedy which were made famous by Lucille Ball and company in the show, "I Love Lucy." For as long as I can remember, I have been watching "Lucy" reruns, but it has been only for the past two and a haif months that I have been watching it critically, investigating and interpreting what has come across my cable television screen. 1 Therefore, what I am about to say in this paper I do not take lightly, for installing cable TV is not cheap and "I Love Lucy" reruns are at 7:00 in the morning!

"I Love Lucy" made its debut in 1951. TV Guide described the show as "revolving around problems arising in a household where the wife is stagestruck and the orchestra leader husband thinks she should stay home." This basic description worked as a golden formula to keep "I Love Lucy" the dominant situation comedy of the decade.2 The show won over 200 awards, while the actors themselves won numerous individual honors and awards. In addition, the show was dubbed in five languages to give foreigners a taste of American comedy too. Literally millions of American people were watching "I Love Lucy" every Monday night at 9:00 p.m. It was the first show ever to have ten million viewers for one episode. One study conducted in 1956 proved that $73 \%$ of adolescent 13- to 14-year old girls chose "Lucy" as their favorite program. What the "I Love Lucy" sitcom formula did for those watching, regardless of age, class, race, or sex, was to simply reflect and reinforce the ideology of the times. According to Gaye Tuchman, this idea can be termed the "reflection hypothesis," meaning "the mass media reflect dominant societal values" (pg. 7). Take this into consideration: In 1950, 4.4 million people owned television sets; by 1956, Americans were buying 20,000 televisions per day. Watching "I Love Lucy" was practialiy an institution in the 50's, but what did the messages and cues of the nation's number one sitcom have to offer? Says Miller and Nowak in their book The Fifties, "it assured them that the American self-image of a nation of wholesome, middle-class consumers was a positive fact of life." That's what the American public wanted and what they received was "I Love Lucy," the message carrier of how an average middle-class, relatively young couple kept the stability of the family intact by keeping the woman out of the work force and in the home as sole homemaker and mother.

It is fairly easy to understand how a situation comedy such as "I Love Lucy" worked so well and was so consistently popular with its TV viewers. Although its formula as a television series can be reduced to a value-laden communicative act, it is not necessarily so easy to do so. Why? Because "I Love Lucy" was and is a very funny show. Says James W. Chesebro and Caroline D. Hamsher, "viewers perceive the series predominantly as entertainment rather than persuasive acts." Thus, attention was almost unconsciously afforded those principles, ideas, and notions repeated from show to show in the "I Love Lucy" series.

"I Love Lucy" was obviously a very powerful force in the media. Anything as popular and pervasive as "Lucy" was, is bound to have great impact on a society which was becoming increasingly involved in watching television. 
In examining "I Love Lucy," it is important to pay close attention to the sitcom formula, and specifically to this formula as applied in "I Love Lucy." The basic formula of Ricky vs. Lucy, Husband vs. Wife, Man vs. Woman proved to display an especially important ideological feature with the man portrayed as bread-winner and dominant. In grinding out this formula episode after episode, Lucy was affectionately termed the "redheaded screwball." Calling the woman and/or wife a derogatory name seems to fit into the general sitcom formula, an immediate image arises of Edith Bunker as "dingbat." Although it was more the media than Ricky who christened Lucy "screwbal1," the image and effect is the same. 3

The 1950's was a reactionary decade which held the American family up as the true symbol of a democratic nation. WWII had been fought and won by American men on foreign soil so they could come home to democracy and family. Women naturally played a very fundamental role in this scheme. But a very contradictory situation was actually occurring: 6 million women had entered the work force during WWII, and by $1945,36 \%$ of all women worked and $30 \%$ of all women working were mothers. This total percentage figure dipped to $29 \%$ in 1950. The men had come from war and the women were forced out of their non-traditional jobs back into the home. The widespread image mass media portrayed of women wanting to stay home after the war ended was false. So what was actually happening was a semicollapse of a paternalistic superstructure leading to preconditions for a feminist movement. Women were discontented and understandably outraged at being shuffled back into the non-productive housewife role after performing so competently and heroically in the productive sphere. The murmurings of change could, in fact, have led to the makings of "I Love Lucy." It was the feminine mystique being created right before women's eyes, a meeting place between old roles and new reality.

"I Love Lucy" is a classic example of the four structures oppressive to women as outlined by Juliet Mitchell. All of them are necessarily and importantly linked, but each can be examined separately.

\section{Lucy and Production}

Judith Lemon (1975) states, "situation comedies offer more possibilities for women to participate and dominate, since they include more family situations and plots about interpersonal concerns." According to Mitchell, this very fact obscures woman's subservience in production and the two combined only serve to compound their oppression. An interesting twist in this concept is present in "I Love Lucy." Lucy was not portrayed as the classic model of a passive, weak wife. She was a strong-willed, aggressive, and ambitious type person. The trouble was, her ambitions many times were focused on benefiting her husband and not herself. Where Lucy failed in her ambitions for herself, she usually succeeded in her ambitions for Ricky. Ricky was nearly always perfect in his symbolic role of man as powerful, man as the head of the family. He went off to work each day while Lucy concocted "scatterbrained" schemes with her cohort Ethyl Mertz back at the homefront. One of the reasons this whole formula is so disturbing to me is not only the fact that Lucy gains her identity from being a homemaker and Ricky's wife, but that she is never actually shown being a worker in the home either. Domestic labor is work, 
hard work and it is generally performed by women. Realizing this, and how the division of labor is traditionally explained as due to physiological differences between the sexes, particularly the differences in muscular strength, then this is grossly unfair. Thus, essentially, Lucy does not even assert a physical strength in work around the home. I see this as a double bind, negative image of a woman's worth in our society. To men, Lucy was an image of why women were not the productive members of society: they were physically weaker and mentally incompetent to be responsible in a job situation. For women, the image Lucy portrayed was damaging because it negated reality and reinforced a cultural idealogy. Women who were now back in the home after tasting and enjoying satisfaction in the work force during the $1940^{\prime}$ 's, rarely saw an ugly side to a day at home with Lucy (and Ethyl). Lucy didn't do housework; consequently we never saw a discouraged, depressed and degraded image more closely reflecting the reality of women at home. 5

Brandon French has seemingly interpreted the character of Lucy in a different and more positive way in her article "We Used to be Different, but Now We're the Same" (Chrysalis, April, 1980). Using the context of the 1950's as a decade "mired in mediocrity, compromise, and fear of extremes, a decade more housebound and hostile to dreams and dreamers" (page 29), French sees Lucy as America's first example of a "picaresque heroine." Don Quixote is one of the best known examples of this form of a hero - one that is something of a rascal and wildly imaginative. Quixote also had a skeptical but loyal companion in Sancho Panza, and together they experienced many an extraordinary adventure. Whether you have watched many or a few "I Love Lucy" episodes, it is easy to see that Lucy's character is a laughable combination of rascal and fertile imagination. Keeping this character description and period of time in mind, we have an image of Lucy and her companion, Ethyl, as a rebellious duo speaking directly to the greater female longing of gaining satisfaction in the outside world and transcending the limits of a defined female role. Of course while Lucy was reaching out and stirring women's desires for change, she was also stirring men's fear of those desires. It is an interesting interpretation of Lucy. For, seen as a rebel of the $50^{\prime} \mathrm{s}$, Lucy shares that distinction only with men; Elvis Presley, James Dean, etc. To interpret the character of Lucy Ricardo in this way gives some evidence to an earlier statement made about "semi-collapse of a paternalistic superstructure." Maybe as feminists there would be no critical evaluation and interpretation of "I Love Lucy" if she had, in fact, carried out and succeeded in her attempts at rebellion and change - but we can't blame Lucy for what the writers came up with.

A good example of the points raised in this paper is the following episode of "I Love Lucy." It is a 1957 episode entitled "Lucy Raises Tulips." Lucy is determined to win the Westport, Connecticut "Best Looking Garden" contest. (Westport is the suburb the Ricardo's moved to in the 167th episode in 1957.) She is convinced she can dethrone her neighbor, a three-time winner, but not without the lawn mowed to perfection. Ricky mows the lawn, but only does half the job before he leaves with Fred to a baseball game. When Lucy discovers this, she decides that she will just have to finish it herself. Of course, the lawn mower itself is a bulky riding type and when Lucy gets on it and surprisingly starts 
it, she is immediately out of control. The machine takes her on an involuntary trip around Westport and through lawns and gardens. She finally crashes in her own yard to stop the thing. Ethyl, who had offered Lucy help by calling the hardware man in hopes of discovering how to turn it off, could only worry and hope that the machine would eventually take Lucy by the hardware store so the man could run out and stop her. The message seems to be "see what happens when women tinker with technology and machines, or "how to mow your neighbor's lawn without really trying." It is clear in this episode that Lucy's best bet for success is growing her tulips and not mowing her grass. And, interestingly enough, the tulip judge was a male which tellis us exactly how a woman's achievement is determined, even in the role in which she supposedly has power.

\section{Lucy and Reproduction}

As Mitchell (1973) states, "Women's absence from the critical sector of production historically, of course, has been caused not just by their assumed physical weakness . . . but aiso by their role in reproduction." One of the true measures of success for the "I Love Lucy" series were the episodes which evolved from and revolved around Lucille Ball's pregnancy in 1952. The show had seemingly come upon a stroke of great luck. What better way existed to demonstrate what kept women out of the labor force and in the home than reproduction itself? When Lucy first found out about her true-to-life pregnancy, it seemingiy meant dissolution of the series. But Jess Openheimer, the producer and also a writer for "I Love Lucy," thought the news was wonderful. After much haggling with CBS and network sponsors, the "Lucy" crew finally got the go-ahead to write and film episodes of Lucy Ricardo as an "expectant mother. "6 The first episode was aired December 8, 1952. It was the show's 50th episode and was entitled "Lucy is Enceinte." "Enceinte" is Latin for pregnant. Following are some lines from this particular episode when Lucy wants to tell Ricky the news. He is home for lunch and in a bad mood:

Ricky: Oh, what a business. Sometimes I think I should go back to Cuba and work on a sugar plantation. Just the two of us.

Lucy: Just the two of us?

Ricky: Yeah. I don't mean to get you all involved in my affairs, but you shouid be happy you're a woman.

Lucy: Oh, I am, I am!

Ricky: You think you know how tough my job is, but believe me, if you traded places with me . . . you'd be surprised.

Lucy: Believe me, if I traded places with you, you'd be surprised.

This first episode preceeded seven more "pregnancy" episodes. The eighth episode proved to be a very interesting one. Although it was probably much to risque to touch on the subject of postpartum depression in an obvious way, this episode came up with its own sneaky title to do so. "The Inferiority Complex" had Lucy retreating to bed in a depressed state with intentions of remaining there for life. In her sensitive state it seems Lucy had managed to tell some lousy jokes and also mess up Ricky's breakfast by oversalting his eggs, leaving the pits in his orange juice, and burning his toast. How depressing to think that Lucy's depression could be lifted by the amount of salt on Ricky's breakfast eggs! 
And so the Ricardo family was launched. Magazines went crazy showing pictures of Lucy, the Mother. It was an ironically opportune time to play down the importance of Lucille Ball's career as a very successful actress. Rather, she was being portrayed and photographed in a similarly characteristic image of Lucy Ricardo, the non-working wife and mother. What a farce, yet what a perfect example of how the public was bombarded with ideology and not reality.

\section{Lucy and Sexuality}

The January 1953 issue of McCall's featured what was called "McCall's Personal Story." Entitled "Why I Love Lucy," this article was by Desi Arnaz as told to someone else. One short paragraph can quickly sum up what I have been trying to interpret through two and one-half months of viewing, a dozen or so magazine articles, and book research! Says Desi: "As Ricky, I love Lucy because in spite of her screwball behavior she has what no man can resist: femininity. Not only does she look feminine, her mind works in a fascinatingly non-masculine way. Granted that she always carries things further than the average wife dares to go - nevertheless, if you ever met a woman then you've met Lucy" ( $p .24)$. And another quote from our pal Ricky: "When Lucy (Ricardo) isn't being jealous, she is usually being ambitious. Ever since I married her she has dreamed of becoming a singing-and-dancing star in my night-club revues - an idea I have continualiy squelched, since I like her as a wife" ( $p .84)$.

This image was indeed repetitive. I read and looked at many magazine articles concerning Lucille Ball and "I Love Lucy" and the same basic notion of Lucy's femininity kept appearing. Perhaps one article comes to mind more easily first because of the title "Beauty Into Buffoon" (Life, Feb. 18, 1952), secondly because of the pictures, and thirdly because of the contents. The basic message went something like this: here we have an obviously beautiful and feminine woman who is willing to cover that up to get laughs by having pies thrown in her face, wearing baggy clown clothes, blackening her teeth, etc. The media was constantly reminding us that if Lucy's television antics seemed a bit unfeminine, it was only for laughs and the show. Consequently, magazines came up with titles such as "Beauty Into Buffoon" and with photographs that showed her wacky characterizations as well as her beauty.

In this way too, Lucille Ball's sexuality was shown. For these above mentioned pictures not only proved her beauty, but also that she was a sexy woman. There was, of course, no socially acceptable way to show this sexual side of Lucy Ricardo. Again, it was more subtle. Ethyl Mertz was Lucy's best friend - we saw them together often. She also wore noticeably uglier and less stylish clothing than Lucy to make her figure appear less attractive. Her weight was often the subject of Fred Mertz's insulting remarks and jokes. As a matter of fact, Vivian Vance (Ethyl Mertz) had it stated in her contract that she should remain 20 pounds overweight for the "Lucy" series. This way the writers could continue coming up with abusive verbalizations to add to the story line.?

Lucy and Socialization

The last structure I want to touch on is socialization of children. 
The most recognizable socialization process occurring in "I Love Lucy" was Lucy socializing "Little Ricky" to be a musician like his daddy. The role model the child was being taught to value more was that of his father, the instrumental half to his parents. Lucy was often the expressive, nurturant model, as shown in the episode "Nursery School" (December 5, 1955). Ricky wants their son to attend nursery school, but Lucy is reluctant to let the child be away from his mother for that long a period of time. Little Ricky ends up going anyway and catches a cold which develops into tonsillitis. He goes to the hospital for a tonsillectomy and when Lucy is told she can't spend the night with him, she is bewildered. During the night, Lucy sneaks back into the hospital, dresses as a nurse, creates total havoc, and finally delivers herself and Ricky's teddy bear to his room where they all sleep together. The birth of Ricky Jr. appropriately occurred early enough in the series to allow the writers to weave this into many of the following 129 episodes. And, as Juliet Mitchell says in Women's Estate (page 115), "In bringing up children, woman achieves her main social definition."

\section{Today's Image}

The most revealing thing about observing a once extremely popular sitcom such as "I Love Lucy" is the absolute parallel of media message and culturally dominant ideology. In looking through popular magazines of the 1950's for articles on "I Love Lucy," I actually felt that perhaps what women are striving for today is not totally falling on deaf ears. But unfortunately I am not quick to be optimistic because television is still resisting what actually is. Today over half of all American women between the ages of eighteen and sixty-four are in the labor force. In addition, most working women are married and many have young preschool age children. That is the reality of our social condition. Women are working because of economic hardship, but also because it provides satisfaction and pleasure in a way the tasks of housewifery cannot. We have actually had practically no images of working wives and/or mothers on television in recent years. Most have failed with the exception of "The Bob Newhart Show" in which Bob's wife, Emily, is a schoolteacher. Yet the title of the show alone is enough to tell us who the subordinate character is. What we have had instead is "Alice," a show about a working widow; the "Mary Tyler Moore Show," about a single, "working girl;" and "Rhoda" and "One Day at a Time," both about working women who are divorced. Why is it that television does not produce shows that have a working wife and mother? Yet I would not be satisfied to have such a show just for the sake of having one; the true worth of having it would come if the portrayal of the woman was positive and meaningful in both the public and private sphere. This might seem a great task considering that ". . . television most approves those women who are presented in a sexual context or within a romantic or family role" (Intro, Hearth and Home, page 13).

It has been almost thirty years since "I Love Lucy" premiered. If you believe Gaye Tuchman's above statement, then "I Love Lucy" apparently was only the beginning. Everything stated in this paper is essentially an attack on the way TV socializes females and males to be two distinctly different kinds of people with two distinctly separate tasks in life. I agree totally with Tuchman when she says: 
"What can the preschool girl, the school girl, the adolescent female and the woman learn about a woman's role by watching television? The answer is simple. Women are not important in American society, except perhaps in the home. And even within the home, men know best, as the dominance of male advice on soap operas and the use of male voice-overs for female products, suggests. To be a woman is to have a limited life divorced from the economic productivity of the labor force" (Hearth \& Home, page 17).

To feel discouraged about women's status on the one hand is to realize on the other how much vitality we can offer to society. 
Footnotes

1. I watched and recorded 18 "I Love Lucy" episodes.

2. John G. Cawelti's definition of formula is: "A conventional system for structuring cultural products." Quoted from "The Concept of Formula in the Study of Popular Literature."

3. Note here also the 1930 and 1940 screwball movies (The Three Stooges, The Marx Brothers, etc.).

4. Work in the home is productive labor, albeit unpaid.

5. For more information see Ann Oakley, Woman's Work (1974) and also The Sociology of Housework (1974).

6. CBS thought the word "pregnant" would upset the public.

7. The image CBS wanted for Ethyl was "frumpy," a fact that eventualiy caused resentment and arguments between Vivian Vance and Lucille Ball. 
Bibliography

Andrews, Bart Copyright 1976; Lucy \& Ricky \& Fred \& Ethyl. First Edition. Published by E. P. Dutton \& Co., Inc., New York.

Miller, Douglas T. and Nowak, Marion Copyright 1975, 1977; The Fifties: The Way We Really Were. First Edition. Published by Doubleday \& Company, Inc., Garden City, New York.

Mitchell, Juliet Copyright 1971; Woman's Estate. Published by Vintage Books, a division of Random House, New York, April, 1973.

Newcomb, Horace, editor Copyright 1976; Television: The Critical View. Published by Oxford University Press, New York.

Rubin, Lillian Breslow Copyright 1976; Worlds of Pain/Life in the WorkingClass Family. Published by Basic Books, Inc., New York.

Tuchman, Gave, Daniels, Arlene K. and Benet, James Hearth and Home. New York: Oxford University, 1978.

\section{Magazines}

Chryal is, April, 1980 "We Used to be Different, but Now We're the Same." Coronet, July, 1953 "What's the Secret of I Love Lucy?"

Life, February 18, 1952 "Beauty Into Buffoon."

Life, April 6, 1953 "Lucy's Boys."

McCall's, January, 1953 "Why I Love Lucy."

Time, May 26, 1952 "Sassafrassa, the Queen." 
HORATIO ALGER IS ALIVE AND WELL AND

MASQUERADING AS A FEMINIST

\author{
or \\ WHERE ARE THE MAGAZINES FOR THE \\ REAL WORKING WOMEN?
}

Teresa Holder 
The resurgence of the Women's Movement and feminism in the past decade has brought changes to popular American culture. A significant number of films, T.V. programs and magazines now present some of the predominant beliefs of the Women's Movement. This new development reflects both the rising popularity of these beliefs and the concomitant presence of a lucrative market that can be tapped through media which present appealing, mildly feminist values. Two relatively new magazines are a part of this trend, Working Woman and Savvy. These magazines are of special interest in that only they are directed expressly at women and their relationship to their work.

This viewpoint is quite a change from traditional women's magazines which place "an emphasis on hearth and home and denigrate the working woman" (Tuchman, p. 257). There is less concern with beauty, fashion, or homemaking - traditionally women's subjects. Women on the whole are taken more seriously here. As highly responsible, competent businesswomen, they are the object of advertising by major corporations. Positive as this change in attitude seems, a closer look at the content of both magazines reveals negative aspects and messages disturbing to feminists.

The most bothersome aspect is the income level of the women featured and the assumed income of the reader. Less than three percent of working American women would fit into this income bracket (The Earning Gap Between Men and Women, U.S. Department of Labor, p. 5). This unreality is tied in with the major recurring themes. Most prominent is the "Woman as Horatio Alger" myth which implies that any woman can become extremely successful and make phenomenaliy high salaries if only she labors with enough dedication. In addition to this theme, the Superwoman is glorified. Such women work hundred-hour weeks and care for husband and family without a free moment. Finally there is the common American message that one must sell oneself in order to get ahead. These messages reaffirm values traditionaliy associated with men, now transferred to women.

This paper seeks to analyze the above themes and aspects of Savvy and Working Woman. The purpose of this anaiys is will be to draw out and clarify the implications of the messages found in these magazines and attempt to determine what social purpose these messages serve. To do this a Marxist analysis is used.

Marxism is based on the tenet that the economic power relations of a society determine the power relationships in every sphere of that society. The class which controls the means of producing wealth determines the content of culture and the nature of social relations. Therefore, in doing a Marxist analys is one initially seeks to pinpoint where economic power really resides. In a capitalist economic system, such as that of the United States, this power is in the hands of the bourgeoisie or upper class. This class benefits and profits from the work of the majority of people, the proletariat or the working class. According to Marx, one's class standing, be it bourgeois or working class, plays the major role in determining loyalties, values and political viewpoint. On the whole, the bourgeoisie tends to hold conservative values and strives to maintain the status quo and their privileged position. These values in turn become the alienated beliefs of other classes. 
One method used to maintain the rule of any given class is through social values and ideals. Marx held that inevitably the ideology which serves the interests of the dominant class will become the overriding ideology of a society:

For each new class which puts itself in the place of one ruling before it is compelled merely in order to carry through its aims, to represent its interests as the common interest of all the members of society, that is, expressed in ideal form: it has to give its ideas the form of universality and represent them as the only rational, universally valid ones (Marx, German Ideology, p. 65-66).

This dominant ideology is clearly that of the bourgeoise. Individualism, self-interest, competitiveness are all highly valued in our culture. Affluence as a sign of virtue, poverty as a sign of worthlessness and the belief in the inferiority of women are all part of bourgeois ideology. These values work to keep people in line by rewarding certain sectors at the expense of others, this situation benefits the ruling class. The role models presented to everyone such as the rugged loner, the individualist who needs no one and the average person who through hard work alone is able to make it to the top serve to reinforce this ideology. The recent emphasis on the Superwoman who can be worker, mother and wife or lover simultaneously with ease stems from this same value system.

The concept of the hegenmony of bourgeois ideology will be used to analyze the content of Savvy and Working Woman. Four issues of Savvy from September through December of 1980 and three issues of Working Woman from October through December of 1980 were my source of data. The technique I used in gathering information was reading both magazines with a focus on the women mentioned and profiled in feature articles. In this way I sought to determine what ideals and role models were being presented. Advice columns on a variety of subjects also included mention of women which frequently yielded useful information. From this data I tried to discover what major, overall themes were emphasized.

A second aspect of my analysis was an examination of the economic status of the women featured and what was apparently the assumed reader income. I averaged all salaries cited for specific women to determine their mean income. To gain a general notion of anticipated readership salary, I looked at the clothes shown in fashion features and salaries quoted in general circumstances. In order to establish the true economic power of the women who were presented in these magazines, I examined their occupation. I concentrated on the number of women in banking and finance, high level executives of major corporations and ownership of large businesses. An attempt was also made to discover if the majority of women were in more traditional female professions such as education or personnel management.

Before presenting the findings, a general description of these two periodicals is useful. Both are full color monthlies, printed on slick paper. Savvy averages about eighty pages and Working Woman about onehundred twenty. Advice columns on investments, banking, Tegal questions, 
career options and techniques needed to land good jobs and gain promotions are found in every issue. At least one feature article every month is on a successful business woman in both magazines. Other features cover a wide variety of topics ranging from the business world, to politics, to health. Always the stress is on the interests of the white, professional woman. Savvy bills itself as the "magazine for executive women" and its graphics, layout and photos are flashy, they bear more resemblance to Esquire than Working Woman. Working Woman, which is much more subdued, has very few graphics and an interior color scheme of dull grey and purple. I felt a more serious image was being projected. No where in Working Woman does it state that it is a magazine for professional women but its orientation is clear immediately. A number of the issues that I looked at contained articles sympathetic to the goals of the Women's Movement. Both Savvy and Working Woman clearly support the ERA and equal opportunity, if not more radical feminist demands.

In my analysis I first examined the incomes of featured women. The mean salary cited in Working Woman was a whopping $\$ 46,107$ per year. Savvy, despite its stated target of executive women, had a lower average of $\$ 32,328$. The general sense of the readers' income does not reflect this same differential. Salaries quoted as examples in advice columns and mentioned elsewhere were higher on the average in Savvy. The income spread was approximately $\$ 20,000$ to $\$ 40,000$ for Working Woman and $\$ 35,000$ plus in Savvy, with a number of references to salaries in excess of $\$ 75,000$. The significance of these differences is problematic. What is important, however, is the very high level of these incomes. Another reflection of the income bracket targeted for the reader are the fashion and accessory spreads. Savvy has a monthly fashion section, clearly aimed at women in the upper financial strata. Featured fashions varied from $\$ 4,000$ skunk capes, $\$ 2,000$ mink-1ined jumpsuits (November, 1980) to more practical suits priced between $\$ 1,200$ to $\$ 600$ (October, 1980). Accessories were a)so expensive. A section entitled "Consuming Passions" (a monthly feature) advertized jewelry ranging from $\$ 50$ to $\$ 2,400$ with the average in the $\$ 300$ area (0ctober, 1980). There was only one fashion spread in Working Woman. This was a professional wardrobe for the woman making $\$ 20,000$ a year (October, 1980). There were no articles on fashion accessories but treatments of kitchen items, autos and Christmas ideas indicated a more moderate income level than Savvy.

These findings show that these magazines are not aimed at the average working woman or even the average woman in management. Although women are entering the workforce in increasing numbers and are now better educated than ever before, pay for women has not improved (Almquist, 1977, p. 843). In 1977 the median income for women of all races in the U.S. was $\$ 8,613$; it was not significantly higher for white women alone (Earning Gaps Between Men and Women, 1972, p. 6). The percentage of women making over $\$ 20,000$ per year was $2.7 \%$ with the bulk of women making between $\$ 7,800$ and $\$ 13,000$ per year (Ibid.)

The large disparity between the income of most women and the salary level in these two periodicals is also reflected in the earnings of the occupations featured most often. The average income in 1978 for women managers in various fields was $\$ 10,000$. Only $6 \%$ of all women managers 
and professionals made salaries above the median for their occupation (Earning Gap, p. 11). Kate Rand Lloyd, editor-in-chief of Working Woman, stated that the average reader of her magazine made around $\$ 16,000$ per annum, yet one would expect this average to be at least $\$ 20,000$ judging from the content of the magazine.

These discrepancies are due in part to the push for people to be upwardly mobile in our society and to consume and spend beyond their means. However, these examples of token women with exceptionally high salaries obscure the truth about working women in America - they are underpaid, underemployed and have very little real economic power.

The lack of financial power among women is demonstrated by the distribution of jobs mentioned in Savvy and Working Woman. Banking and finance positions made up only $\overline{3.8 \%}$ of the occupations noted in Working Woman and $2.8 \%$ of those in Savvy. Most of these women were bank vicepresidents. Executive positions in large corporations made up $7.6 \%$ of the jobs in Working Woman and in Savvy they were $8.5 \%$ of the total. The financial power and responsibilities of some of these executive positions was unclear. For example, I am not sure what the vice-president of creative services for Colgate-Palmolive does. The absence of women who own any major businesses is another indication of their economic powerlessness.

Actually there was one female financier mentioned. Sandra Brown was featured in Savvy after being indicted on several counts of fraud. Her empire had been supposedly worth 35 million dollars, but apparently was ficticious (Welles, Chris "Money Manipulation Catches Up with Sandra Brown," Nov., 1980, p. 28). The treatment of this woman serves as a warning to other women who might attempt to gain some real economic control via big business. Sandra was apparently motivated by insecurity and "a self-destructive quality" to perpetrate fraud. She, we are told, was "childlike in other ways. During times of crisis she often burst into prolonged tears" (ibid., p. 31). The male author also informs us that positive reports on Ms. Brown in the past were due to misjudgments based on a "zeal to herald the heroic attainments of an attractive young woman in an especially male-dominated part of the business world" (ibid., p. 30). Clearly, with Savvy's help that part of the business world will remain male-dominated for some time to come.

The presence and absence of other occupations in both magazines was fairly evenly distributed. For example, no professions currently dominated by women were mentioned. Management was the most represented group in Working Woman at $17 \%$ of the total. Savvy featured journalists most often. Nineteen percent of all jobs mentioned were in television or magazine news work. With the interesting exception of an article on clerical workers in the December Working Woman (Field, Anne, "The Management, " p. 68), all the jobs featured in both magazines were upper-level white collar positions with a touch here and there of art and literature.

Obviously most women in the U.S. are not working in these fields. The fact that these two are the only magazines directed at women who work brings up the question: Where are the magazines for the majority of working women? Women in trades and factory work need as much support as women 
in management. This domination of the media by white upper middle class figures is not a phenomena of women's magazines alone. Lower and working class women and men and people of color have almost no positive presence in the mainstream of our culture. Blue or pink collar women are especially absent. They are faced with double annihilation. As women, they are erased through patriarchal culture, and as proletarians they are absent in bourgeois culture.

A number of components of this American bourgeois culture can be seen in common themes found in the feature articles of Savvy and Working Woman. First and foremost of these themes is the Horatio Alger myth mentioned above. Over and over again, these magazines present the reader with women who have climbed right to the top because of their hard work and talent. This theme varies with each magazine. It is somewhat less prominant in Savvy whose women tend to be entrepreneurs. "One Fantasy, Two Women, $\$ 100,000 "$ is the story of two women who, with "only" $\$ 100,000$ and a lot of style create in less than six years one of the best gourmet restaurants in New York. This enterprise "grosses moreover one million dollars a year" (Canatrow, Ellen, Savvy, October, 1980, p. 42). Another article is about a woman who started an art gallery and in two years was doing half a million dollars worth of business (Goldberg, Vicky, "The Artist in Search of a Gallery," Savvy, September, 1980, p. 54).

Working Woman more often features women who climb the corporate ladder with great success. The youth of these women is usually emphasized. For example, one woman profiled was making $\$ 150,000$ a year as a VicePresident of General Mills at the age of thirty-six. Another story is about a young woman who rose in five years from script writer to VicePresident of a movie studio. An extra-corporate example is the model turned stockbroker who was making $\$ 135,000$ a year at the age of thirtyone and is now a very successful caterer. These women are a 11 presented as talented but above all, they got where they are through hard work and determination.

The message of these life stories is clear enough: any woman who really wants to can become weaithy and successful if she works hard. This myth keeps women working within the system, in the hope of possibly "making it big." Women are thereby encouraged to work hard, produce more and be helpful, in other words, to be more profitable employees. The Horatio Alger myth in the guise of feminism helps to turn women's energy towards individual advancement rather than towards eradicating the roots of women's problems in our society.

The myth of the Superwoman aiso serves many of these same purposes. As more women move into the work force, the ideal of the Superwoman has become part of the social expectations for working women. These women who do it all and do it well are featured often in both of these periodicals. In a Savvy article (Cunningham, Ann Marie, "The Time Pressured Life," December, 1980, p. 38) on such women one finds a somewhat ambivalent attitude towards Superwomen's 1 ives. Women are featured who trave] $80 \%$ of the time, work hundred-hour weeks, and have children and husbands to care for. In this article for once there is severe, explicit criticism of heavy professional demands which jeopardize the rest of one's life. 
The double standard for family men and women is also criticized. However, it is made clear that these women are happy in the only existence they believe can bring them fulfillment.

Working Woman also features Superwomen. Many work incredibly long hours, raise families, and run businesses. Although the problems of such a stressful existence are recognized, their articles insist these long hours are necessary to get ahead. "You can't work 9 to 5 and be a high level successful executive .... The competition isn't working 9 to 5 ," according to George Ball, President of E. F. Hutton (November, 1980, p. 94).

The Superwoman ideal is the bourgeois work ethic carried to the extreme and applied to women. It serves the purposes both of sexist ideology and the capitalist economy. The Superwoman ideal makes women feel inadequate if they cannot both work and fulfill their family role. This idea gives the economy women recruits dedicated to hard work without disturbing their traditional economic contribution to society and the family.

Two additional themes that are also examples of traditional bourgeois values need to be noted. Strong individualism is expressed in the profiles of many of the women in both magazines. Some express a sense that they made it to the top on their own with no assistance from the women's movement or anyone else. Their success is due to their own particular talents. They do not picture themselves as women who made it but as an individual no different from a man. In a 1979 study of women lawyers and academicians Della Cava and Engel found many of these same views. The women's selfdescriptions were "an almost stereotypical description of the American hero, the rugged individualist battling his way through life" (p. 505).

Individualism separates people in our society and plays a vital part in rationalizing our economic system. Not only does it justify the exploitation of many by one entrepeneur but it serves also to isolate those being exploited. It holds out to them the belief that a person working alone through the system can achieve ultimate success.

The belief that people must sell themselves is the other theme. This view of human beings as a commodity is a reflection of our economic system. People are hired and fired, bought and sold in a process beyond their control. This is one of the most pervasive images in our popular culture, especially for women.

In Savvy and Working Woman, most of the "sell yourself" messages are concerned with how to land a good job. The message is that women must "sell themselves, perceived as a commodity like every other article of commerce and are consequently exposed to all the fluctuations of the market" (Marx, Karl, "The Communist Manifesto," p. 148). More subtle ways of selling oneself are seen in advice on how to maintain and create the right image. Face lifts, sports cars, eating in the right place and spending up to $60 \%$ of your income on your image are presented as means to remaining an attractive commodity on the job market.

These magazines are in some respects an improvement over their predecessors. They are very supportive of women in non-traditional upperlevel jobs and women trying to climb the corporate ladder. Although 
many women in these magazines felt that they had made it on their own, there was implicit support of the Women's Movement in criticisms made of this attitude by some other featured women. They conveyed a sense of how hard women had to fight and that they had, with others, united to gain whatever reforms had been made. These working women are also attempting to build networks of contacts between each other to counter the old, established male network. Working Woman at least gives some indication that it may expand its appeal. The December issue contained a lengthy article on the difficulties encountered by women trying to organize and unionize clerical workers, with is an interesting point of view in a magazine directed exclusively at management.

However, if feminists are dedicated to ending the oppression of women, it is difficult to see in what way the attitudes presented in Savvy and Working Woman can serve that end. These views will only encourage and assist the individual, career-minded woman to achieve success. The needs of the majority of women in our society remain unaddressed. The assimilation of values and ideals of the male business establishment is very disturbing. Is it a great improvement for women to support our exploitive economic system with as much skill and zeal as men, with no difference? Instead, don't feminists seek to "destroy structures of sexual, racial and class hierarchy?" (Eisenstien, 1979, p. 51). These magazines are to the economy what Playgirl is to sex. They are "proof" that women can be as exploitive as men are about sex and the labor of other people. Though they claim to be feminist, Working Woman and Savvy never present their views on the underlying cause of women's oppression in our society and what should be done about it. Their blanket acceptance of the entire male financial system indicates a basic lack of understanding. Hopefully, this analysis has made clear the implications of this oversight. Clearly "none of the processes in which a woman engages can be understood separate from the relations of the society which she embodies and which are reflected in the ideology of society" (Eisenstien, p. 47). 


\section{Footnotes}

1. The Upper Class owns and controls the large corporations and businesses of this country and the world. The class division in the U.S. has become somewhat ambiguous. There has been a recent emergence of a strata of highly paid managerial workers who do not own businesses although their loyalties lie with the bourgeoise. The values and attitudes of the American working class have many bourgeois characteristics due in large part to the privileged position of the U.S. proletariat in relation to the workers in the rest of the world. The global economic dominance of the U.S. enables the American working class to avoid the severe poverty and exploitation experienced by most of the world's lower classes. The control of the socialization process by the ruling class is also a key factor in creating a working class that identifies with the bourgeoise. 


\section{Bibliography}

Almquist, Elizabeth M. "Women in the Labor Force," Signs: Journal of Women in Culture and Society, Summer 1977, Vol. 2, No. 4.

Della Cava, Frances and Madaline H. Engel, "Resistance to Sisterhood: The Case of the Professional Woman." International Journal of Woman's Studies, Nov./Dec. 1979.

Eisenstien, Zilla, Introduction in Eisenstien, ed. Capitalist Patriarchy and the Case for Socialist Feminism, 1979, N.Y.C., N.Y., Monthly Review Press.

Engels, Frederich, Origin of the Family, Private Property and the State, 1942, N.Y.C., International Publishers.

Hamilton, Roberta, The Liberation of Women: A Study in Patriarchy and Capitalism, 1978, London, George Allen and Unwin.

Marx, Karl and Frederich Engels, "The Communist Manifesto" in Capital, The Communist Manifesto and Other Writings by Karl Marx, 1959, N.Y.C., N.Y. Modern Library.

Marx, Karl and Frederich Engels, The German Ideology, 1979, N.Y.C., International Publishers.

Savvy: The Magazine for Executive Women, Sept., 1980, Vol. 10; Oct., 1980, Vol. 1, No. 11; Nov., 1980, Vol. 1, No. 12; Dec., 1980, Vol. 1, No. 13.

Tuchman, Gaye, "The Impact of Mass Media Stereotypes Upon the Full Empioyment of Women," in Cohn, Anne Foote, ed., Women in The U.S. Labor Force, 1979, N.Y.C., N.Y., Praeger.

U.S. Department of Labor, Office of the Secretary, Women's Bureau. The Earning Gap Between Men and Women, 1979.

Working Woman, Oct., 1980, Vol. 5, No. 10; Nov., 1980, Vol. 5, No. 11; Dec., 1980, Vol. 5, No. 12. 
FREUDIAN TRADITION VERSUS FEMINISM IN SCIENCE FICTION

Karen Keller 


\section{THESIS}

Traditionally science fiction has had a Freudian base for its extrapolations, but the new feminist writers of science fiction are ignoring that tradition to build a distinctively feminist and egalitarian literature. 
Science fiction offers writers the opportunity to change, revamp and redefine society and the world as they could exist in the future or in different time dimensions. However, traditional science fiction does not change the sexist roles in our culture. Instead, they use Freudian ideas to reinforce the existing, traditional sex roles. One of the primary reasons for this perpetuation of sexual stereotypes is that science fiction, until the $1960^{\prime} \mathrm{s}$, was written predominantly by men for a male audience, the premise being that the female mind was incapable of dealing with science and extrapolations. 1

This is an interesting paradox considering the fact that science fiction was invented by a woman. In 1816, Mary Shelley, who was keenly interested in scientific progress, wrote Frankenstein. 2 When men viewed her invention as a viable literature, they took over the field. Not until the 1960 's did female names become more common as authors of science fiction. This is not to say that there were not female writers of science fiction during this time, but they were writing under male names so they would be allowed to be published and read seriously. But the male dominance in science fiction is statistically very high. There were 20 male readers for every one female reader and only one in fifty writers of science fiction was female. 3

Today, things have begun to change for the better. Feminist writers have struggled to bring new value systems and roles into their works. Ursula Le Guin deals with androgyny in Left Hand of Darkness. She has created a world where every individual is male and female, every individual experiences being a father and a mother. Lynn Abbey presents a strong heroine who is perplexed by the sexually backward society that resembles our own. The androgyny presented in these two feminist books is very positive. El len Morgan says of the feminist presentation of androgyny:
"the feminist novel of androgynous fantasy, suggests that the nonfeminine in women is their natural humanity and that it should not be suppressed." 4

Other feminist writers have dealt with similarly deeply rooted social mores: they provide new definitions and new futures. James Gunn says that science fiction is one of the few things in life that broadens our horizons rather than narrowing our outlook. 5 It's very encouraging to see feminist writers adding visions of equality and enlightenment to that broad horizon. These writers are also giving us, as women, role models to admire and emulate, something long overdue.

Before drawing on some basic Freudian theory to evaluate its application or non-application in traditional and feminist science fiction, it is necessary to lay out several theoretical assumptions.

Science fiction is defined here in the broadest sense, including both science fiction and science fantasy. Science fiction is based on scientific technology and is generally in the future. Science fantasy is more firmly rooted in sorcery and the world of the magical. Science fantasy is usually in a time dimension, of ten with a medieval setting. But for our purposes they will be referred to as the same thing: a literature 
which offers a world different from ours. They are combined because both areas share the traditional male dominance and the recent feminist upsurge. Also, both forms offer feminist writers unlimited horizons in terms of theme, social values, characters and attitudes.

The first basic premise of Freudian theory used concerned the symbolic significance of the penis. Men have access to power and the penis is the symbol of that power. Women, by definition of their castration, are powerless. Men can overcome their castration complex (when they realize they have a penis, like the father figure and resolve the 0edipal crisis), they develop a strong super-ego or the ability to tell the difference between right and wrong.

Freud explained the Oedipal Complex as a relationship between the warm, nurturing mother figure, the son striving for power and the powerful, strong father figure. The son, although first strongly attracted to the mother, turns from her when he discovers her weakness, her lack of a penis. In addition, he faces the more powerful father and his potential to castrate or harm the son. The son then reaches a crisis and resolution where he acquires a strong super-ego and realizes that he possesses a penis like the father. The woman never has this resolution, so she still has a weak super-ego, so she must be told what to do by men; she is weak, indecisive and emotional (Freud, 1923).

So the lack of a penis is the basis for two of woman's most often held positions, mother and sex object, which are viewed as inferior or secondary. The role of sex object merely projects the woman as an outlet for the man's id which must release sex and aggression. 6 The role of mother is seen as one of the only positions a woman can maintain and yet, even in that position, the woman usually depends on the man for support and major decisions.

Traditional science fiction novels use these Freudian theories as an ideological base.

The term feminist will apply to the science fiction novels in which the preceding sexist attitudes and actions are not regarded as admirable. The book, Daughter of the Bright Moon, as a feminist example, will reject the phallocentric ideology by placing a woman in the prime position of power. The woman is also portrayed as strong, with a strong super-ego. The lack of penis worship removes the Oedipal Complex and the fear of castration. Abbey also endows her main character with nurturant qualities, proving that one doesn't need to be weak and dumb to be a mother. The main character will prove herself to be intelligent, physically adept, decisive, rational and logical, dispelling the theory that only men can possess those traits.

I chose to compare a traditional science fantasy book, Karl Wagner's Conan, and a feminist science fantasy book, Lynn Abbey's Daughter of the Bright Moon. The books and magazine articles that I used as secondary sources helped to explain the phenomena I found in the traditional versus feminine versions of science fantasy. There are many different themes in science fiction and fantasy than the ones portrayed in these two books, 
but the character types and social standards are very typical for traditional and feminist science fiction and fantasy.

Conan is a very traditional science fantasy. In the prologue, Conan plunges us directly into Freudian theory. Conan, the youthful hero, is dueling with Captain Rinnova. Conan subdues Captain Rinnova by attacking his central source of power and manhood:

"The end of the blade caught the older man in his crotch and continued upward."7

This castration is Captain Rinnova's death and his loss of power. The women in Conan, also lacking a penis, are just as effectively subdued in terms of power, though they are allowed to live.

Captain Rinnova also symbolizes the Freudian father figure to Conan, the youthful son. Only through the father's loss of his penis, can the son overthrow him and gain the power that the father possessed.

The very first chapter in Conan gives us a shocking example of the Freudian penis worship. While criminals are being hung, their semen is being sold in phials.

"'Seed of a dead man!' cried another, brandishing a small phial. 'The death-spend of Vulosis, the famous murder-rapist! Men! The vitality of a young stallion is yours! Ladies! Restore your man to the ardour of a young bull! Hanged man's seed! Who will buy?" "8

Even though the man was a violent murder-rapist, people are buying his semen since murder and rape prove he was a virile man. This is an example of how the powerful penis is both feared and loved.

Conan keeps his masculine ego intact on the scaffold by showing no 'feminine' emotions, he "stood straight and glowered his silent contempt." 9

Conan is rescued from death by the rebels and revolutionary group, the While Rose. They retreat to the Pit. Not only is the Pit a protecting haven but it is located underground with secret tunnels, a very womblike description. Also significant is the fact that the haven has never been attacked. It is still virginal, its tunnels having never been trespassed.

The son whom the mother figure, the Pit, is protecting and nurturing is the revolutionary group, the White Rose. However, the Pit begins to lose her power as her son begins to mature and seek more power. The son, the White Rose, realizes the powerlessness of the Pit (or the castration of the mother), and attempts to gain the position of the father figure, King Rimanendo. When the threatening father figure does attack the Pit, it is a battle between father and son. The Pit has lost its protective mothering position and has been symbolically violated, no longer the pure virgin.

The fact that the Pit is no longer virginal and pure is also due to the infiltration into the rebel faction of an evil sorcerer, Callidios. 
Symbolically, the Pit is raped not only by the father but also by the son whom she has been protecting. This represents the fact that both the father and son view the mother as imperfect and inferior after discovering her lack. It is also a representation of the id releasing sex and aggression.

Another sanctuary is present in Conan which represents a mother figure, the sorceress Destandasi's home. It is a small round clearing in the midst of an impenetrable forest, intruders are kept out by a magical force surrounding it. It is very representative of a woman's vagina and uterus. The fact that there is no discernible path to the clearing symbolizes the sorceress' virginity. It also represents the womb where Destandasi grew from a small fetus or weak sorcerer to a fuller knowledge of sorcery. She only left the womb when she was strong enough to defeat death in the person of the sorcerer Callidios.

Another feature of Conan that exemplifies the absoluteness of male power is the Final Guard. The Final Guard was one thousand of King Kalenius' elite warriors who were transformed into living black stone to protect his tomb. These men are inconquerable, the only person who can control them is King Kalenius (who has been dead for centuries). The Final Guard was quiet until they came out of the symbolic mother's protective womb of King Kalenius' underwater tomb. Then they cast aside inactivity, left their mother's protection and strove for power. Even their color, black, suggests a strength not assumed in virginal white.

There were only two women in this book who were not referred to as only sex objects, Sandokazi and Destandasi. All the other women are referred to in very inferior sexual terms:

$$
\begin{aligned}
& \text { "merry wench," "supercilious trull," "bareflesh was cheap } \\
& \text { tonight," "painted hoydens," "serving wench," bitch," "high- } \\
& \text { born tart," "slut," "no austere maiden," "doxy," "whore," } \\
& \text { "buxom attendant," "grinning whores," "cavorting sea nymphs," } \\
& \text { "tired-faced whores." }
\end{aligned}
$$

We first see Sandokazi astride a horse, riding with her brother, Santiddio and her lover, Mordermi. She soon loses her admirability. She tries to seduce Conan, who has become a close friend of Mordermi. She betrays her brother's cause for her lover, who then betrays her, and she never goes anywhere or is allowed to do anything by herself. Sandokazi follows the Freudian theory that the woman occupies a secondary position in society and that after provoking the crisis, she becomes a passive observer. She provokes the crisis by betraying Santiddio. Mordermi is the father figure and Sandokazi the mother figure whom he controls. Santiddio, as the son figure, realizes Sandokazi's powerlessness and symbolic castration. This leads to Santiddio's rejection of Sandokazi and his realization of his own power.

Destandasi is introduced negatively as an evil sorceress, who has besmirched the good family name. She is not a main character long enough to be sexually approached by men and her religious bent and support of "Life," give her a clean, virginal appearance and character. It is interesting 
that when she and Conan climb the tower to combat Callidios' evil sorcery, Destandasi is wearing boys' clothing. Only through a man's disguise is she allowed to seek power and attain it by conquering Callidios.

Destandasi exerts the greatest power shown in the book because she is the only one who can stop the Final Guard. But since it is impossible for a castrated woman to hold the position of power which should be accorded her for this feat, she conveniently falls through a trap door to be impaled on spikes below. The trap was set by a man whose power she had threatened. The woman is conquered by phallic spikes. Because she was striving for power not allowed to her within this system, she was castrated again.

In character relations, Sandokazi and Destandasi are both mother figures. Sandokazi is a mother figure to Santiddio and Mordermi, in that she is emotionally supportive and nurturant. Destandasi is a mother figure to the entire populace; her sacrifice protects and saves them from the horrors of Callidios' evil.

Rimanendo, Mordermi, Callidios, Santiddio and Conan represent the primal horde. They are each striving for the position of power, thirsting for absolute leadership. Mordermi and Callidios achieve power but by an external means, their internal super-egos have not mastered power yet. Santiddio finally achieves power but only with the help of Destandasi, the mother figure and Conan.

Conan also represents the father figure in that his super-ego is well developed, his sense of right and wrong is infallible. He possesses power through his intellect and his strength. Although he struggles with the other men for the power of leadership, he has consistent power through the entire book. The other men respect and fear him. He brings the narrative to a crisis by storming Callidios' tower with Destandasi. He confronts the threat of Callidios and Mordermi, and he resolves the story by killing Callidios and Mordermi and making Santiddio ruler.

Swords, overtly phallic symbols, are the main means of protection, survival, and power. Conan symbolically proves his superior power by sporting the largest sword, a broad sword. And of course, he is the best swordsman in the land.

Swords are also the main means of defense in Lynn Abbey's Daughter of the Bright Moon, but the traditional phallic symbol is wielded by a woman, thereby losing its male specificity. Rifkind, the female Asheeran warrior, is by far the strongest character in the book. She is a capable warrior who has existed alone on the desert wastelands of Asheera.

She does not fit the mold of sex object. She dresses functionally. She sits astride a horse rather than contentedly beside a hearth. But she is also a Healer which is a very nurturing role. Abbey has created a very strong androgynous female who defies any Freudian characterization.

Rifkind, rather than having the weak super-ego Freud attributes to all women, possesses a very strong super-ego. She possesses a strong sense 
of right and wrong and the decisiveness to act on those perceptions. She is also very aware and satisfied with her identity as Rifkind, womanwarrior. Rifkind says in challenging An-Soren's chimera, "I am Rifkind, survivor and exile, master of the sword, mistress of the rituals. "Il She strongly asserts her confidence and self-worth when she says, "My name is my pride, my power." 12

Ejord, the most prominent and favorable male character, also possesses a strong sense of right and wrong. The difference lies in the fact that he treats the delineations more emotionally:

Ejord was a sturdy, capable fighter, but he lacked a proper understanding of survival. Even as a healer, she knew when to dissociate herself from the impossible. The queen's spirit was locked at that instant of time - it was in torment but she couldn't release it without unacceptably jeopardizing her own safety. . . . 'Do something for her!' Ejord shouted as another scream rent the room, and the compound.

'What was the queen has now become a tool for An-Soren. I must not be deceived into false pity which would only destroy me.' (Rifkind). 13 sexual.

Between Ejord and Rifkind, we see an emotional bonding, but it is not

Ejord was friendship and mutual respect, she could not yet conceive of love or trust, but . . . friendship was a powerful lure away from the life of exile she saw for herself if she did not join with him. 14

Ejord needs her to help protect his land as much as she needs him. This relationship is not based on male dominance, in fact, it is taken out of the whole realm of dominance and based instead on equality. Neither Rifkind nor Ejord treat or view each other as inferior. Rather than reversing Freud's analys is of sex roles, Abbey has justly written them out of existence.

Rifkind is not only a strong warrior and an equal to Ejord but also a Healer and teacher to Linet. Rifkind saves Linet from the bandits who killed Linet's family, then she uses her healing powers to save Linet from her raging fever. Rifkind then assumes the responsibility of Linet entirely. She gives her companionship, knowledge and protection. She saves Linet two more times, showing that women can provide protection and sanctuary. It is a common feminist theme that men are not necessarily the only or best source of protection, rather women can be other women's greatest protectors.

Rifkind also exhibits tremendous patience and tolerance, not only for Linet but for a whole culture that she does not agree with. This male dominated society acts as a foil to make Rifkind appear even stronger and more admirable. The tolerance she exhibits directly contrasts with Freudian theory. The Freudian figure of power, the father, does not respect 
the differences of the mother, rather he views her as inferior, both physically and mentally lacking. Only with the tolerance Rifkind exhibits, can any kind of equality exist, sexual, racial, or social.

Rifkind takes the active role in the narrative structure. Freund mistakenly labeled "the active" as male. She brings the narrative to a crisis by strengthening her powers and confronting An-Soren, who is the villain, and a threat to all Dro Daria. Through the power of the two rubies, An-Soren and Rifkind's powers are equal and they reach a stalemate. With the removal of the rubies, they engage in physical combat where Rifkind proves her stamina and adeptness to best An-Soren. An-Soren's undoing was one second of self-indulgent pride and hatred:

"An-Soren hated her and reveled in the wound he'd given her, his guard was late - too late this time." 15

After defeating An-Soren, Rifkind and Ejord flee from the burning castle and Lord Humphrey. In their escape, we get another example of Rifkind's belief in fair play, moral right and wrong:

Rifkind yanked the poisoned spike out of her hair, scratching its waxy surface as she did to activate the poison. It was rock-snake venom, fast-acting and always fatal, with the added horror of turning its victims blue. There was no antidote. It was a long throw but fortune shone on her... The spike was one of her oldest weapons, but she'd never used it before. Poison as a weapon - even a last weapon - was distasteful to her as a healer, though the gruesome spectacle of the cyanotic man with his bulging eyes and protruding tongue had probably saved her life, as it had always been intended to do. 16

Rifkind would much rather fight her battles with a sword. The position of power and the respect given that power was not an end that justified any means. This truly demonstrated Rifkind's well-developed ego.

Rifkind's victory over An-Soren and her ability to save a culture a]ien to her, are counter to Freud's phallocentric assumptions. Rifkind proves the invalidity of penis worship - strength and power do not come by sex alone.

\section{CONCLUSION}

The knowledge that more books like Daughter of the Bright Moon exist is exciting and reassuring to me as a woman, an individualist, a feminist. Women authors are struggling against male dominance in the literary fields of science fiction and they are winning that struggle. Pamela Sargent, Ursula Le Guin, Joanna Russ, Anne McCaffrey, Lynn Abbey and Kate Wilhelm are just several of the many women who are now writing inspiring science fiction. These feminist writers are not only putting the sexist theories of Freud to rest, but they are also seizing the chance to provide role models for women, something desperately needed for a long time. The female heroines are examples of women of power, intellect, compassion and strength. They are redefining 'female.' Strength replaces weakness, 
intelligence replaces vapid brain cells, compassion and empathy replace frivolous emotionality and power replaces passivity. And the end result is an admirable individual, a human being who is also a woman.

Tanith Lee gives us a strong woman warrior, Jaisel, in her story "Northern Chess." Jaisel has been beset by the same barriers all women confront and she determinedly overcomes them. Her readers are inspired to have the same confidence and determination.

After all, her entire life had been a succession of persons, things, fate itself, trying to vanquish her and her aims. From the first drop of menstrual blood, the first husband chosen for her at the age of twelve, the first (and last) rape, the first swordmaster who had mocked her demand to learn and ended setting wagers on her - there had been so many lions in her way. And she had systematically overcome each of them. Because she did not, would not, accept that destiny was unchangeable. Or that what was merely named unconquerable could not be conquered. 17

Feminist writers of science fiction are conquering the age-old Freudian theories and writing their way to new and exciting worlds. They are providing hope for a different future, a feminist future and by definition, an equal and healthy way of life for women and men. 
Footnotes

1. Anne McCaffrey, "Romance and Glamour in Science Fiction," in Reginald Bretnor's Science Fiction, Today and Tomorrow, p. 279.

2. James Gunn, The Discovery of the Future, p. 7.

3. McCaffrey, op. cit., p. 280.

4. Ellen Morgan, "The Feminist Novel of Androgynous Fantasy," Frontiers, p. 41, November 3, 1977.

5. James Gunn, The Discovery of the Future, p. 14.

6. Yankelovich \& Barret, "The Psychic Apparatus," p. 67.

7. Karl Wagner, Conan - The Road of the Kings, p. 3.

8. Ibid., p. 9 .

9. Ibid., p. 14 .

10. Ibid., p. 1-209.

11. Lynn Abbey, Daughter of the Bright Moon, p. 22.

12. Ibid., p. 24.

13. Ibid., p. 361 .

14. Ibid., p. 405.

15. Ibid., p. 378.

16. Ibid., p. 397-398.

17. Tanith Lee, "Northern Chess," in Jessica Salmonson's Amazons!, p. 182. 
Bibliography

Abbey, Lynn Daughter of the Bright Moon, New York: Ace Books, 1979.

Annas, Pamela "New Worlds, New Words: Androgyny in Feminist Science Fiction" in Science Fiction Studies, \#15, Volume 5, Part 2, July 1978, p. $142-155$.

Gunn, James The Discovery of the Future, Texas: Texas A\&M University Library, $19 \overline{975}$

Honey, Maureen "Feminist Themes in Science Fiction and Fantasy," paper presented at Popular Culture/American Culture Association, April 16-20, 1980, Detroit, Michigan.

McCaffrey, Anne "Romance and Glamour in Science Fiction," in Reginald Bretnor's symposium Science Fiction, Today and Tomorrow, New York: Harper \& Row, Publishers, 1974.

Morgan, Ellen "The Feminist Novel of Androgynous Fantasy," in Frontiers, Volume II, Number 3, Fall 1977, p. 40-49.

Rankin, Ginny "Women and Science Fiction - Possible Futures," in The Second Wave, Volume V, Number 2, Summer/Fa11 1980, p. 7-11.

Sarmonson, Jessica (ed.) Amazons!, New York: Daw Books, Inc., 1979.

Sargent, Pamela (ed.) The New Women of Wonder, New York: Vintage Books, 1977.

Wagner, Karl Conan - Road of the Kings, New York: Bantam Books, Inc., 1979.

Whitehurst, Carol "Images of the Sexes in Science Fiction," in International Journal of Women's Studies, Volume 3, Number 4, July/August 1980, p. 327337. 


\section{About the Editor and Author of the New Introduction}

Mary Jo Deegan, born in 1946, earned her Ph.D. in sociology at the University of Chicago (1975). She is Professor Emerita of sociology in the University of Nebraska-Lincoln where she taught for 40 years (1975-2015). Mary Jo is currently Executive Director of the Jane Addams Research Center in St. Joseph, Michigan, and remains a feminist theorist. She co-taught, with Terry Nygren, the course "Wimmin in the Mass Media" in the Centennial Education Program at the University of Nebraska-Lincoln during 1980. Deegan's specialties include the sociology of disability, the sociology of women, and the history of sociology. She is the author/editor/co-editor of twenty-three scholarly books and many articles. Mary Jo won the American Sociological Association/History of Sociology (ASA/HOS) section's Distinguished Scholarly Publication/Book

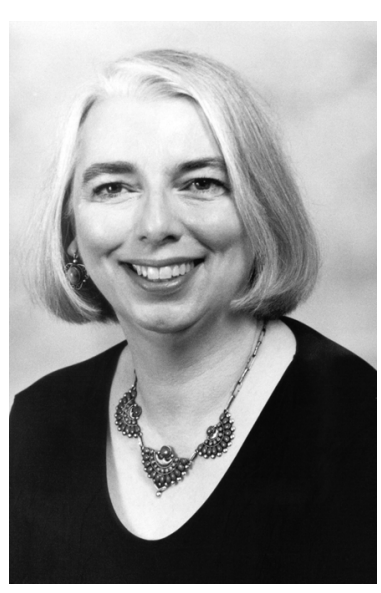
Award in 2003, 2005, 2008 and 2009. Professor Deegan was honored with the ASA)/HOS section's Distinguished Scholarly Career Award in 2002 and, in 2008, with the ASA Peace, War, and Social Conflict section's Robin M. Williams, Jr., Award for Distinguished Contributions to Scholarship, Teaching, and Service. She now lives and works in southwestern Michigan with her life-partner, Michael R. Hill, and their energetic Jack Russell Terrier, "Annie Marion MacLean."

Previous Zea E-Books by Mary Jo Deegan

Michael R. Hill \& Mary Jo Deegan, eds. 2016. Dogs \& Society: Anglo-American Sociological Perspectives (1865-1934). Zea E-Books. Book 46. https://digitalcommons.unl.edu/zeabook/46/ 